\title{
Fine-scale hydrologic modeling for regional landscape applications: the California Basin Characterization Model development and performance
}

\author{
Lorraine E Flint ${ }^{*}$, Alan L Flint ${ }^{1}$, James $\mathrm{H}$ Thorne $^{2}$ and Ryan Boynton ${ }^{2}$
}

\begin{abstract}
Introduction: Resource managers need spatially explicit models of hydrologic response to changes in key climatic drivers across variable landscape conditions. We demonstrate the utility of a Basin Characterization Model for California (CA-BCM) to integrate high-resolution data on physical watershed characteristics with historical or projected climate data to predict watershed-specific hydrologic responses.

Methods: The CA-BCM applies a monthly regional water-balance model to simulate hydrologic responses to climate at the spatial resolution of a 270-m grid. The model has been calibrated using a total of 159 relatively unimpaired watersheds for the California region.

Results: As a result of calibration, predicted basin discharge closely matches measured data for validation watersheds. The CA-BCM recharge and runoff estimates, combined with estimates of snowpack and timing of snowmelt, provide a basis for assessing variations in water availability. Another important output variable, climatic water deficit, integrates the combined effects of temperature and rainfall on site-specific soil moisture, a factor that plants may respond to more directly than air temperature and precipitation alone. Model outputs are calculated for each grid cell, allowing results to be summarized for a variety of planning units including hillslopes, watersheds, ecoregions, or political boundaries.

Conclusions: The ability to confidently calculate hydrologic outputs at fine spatial scales provides a new suite of hydrologic predictor variables that can be used for a variety of purposes, such as projections of changes in water availability, environmental demand, or distribution of plants and habitats. Here we present the framework of the CA-BCM model for the California hydrologic region, a test of model performance on 159 watersheds, summary results for the region for the 1981-2010 time period, and changes since the 1951-1980 time period.
\end{abstract}

Keywords: Water balance; Basin models; Watershed hydrology; Climate change; Downscaling; Basin characterization model

\footnotetext{
* Correspondence: Iflint@usgs.gov

${ }^{1}$ Water Resources Discipline, U.S. Geological Survey, Placer Hall, 6000 J Street,

Sacramento, CA 95819-6129, USA

Full list of author information is available at the end of the article
} 


\section{Introduction}

Many current efforts aimed at climate change impact assessment and adaptation planning focus on water availability for both human populations and ecological systems (e.g. Trnka et al. 2012; Parmesan 2006). Projections of future climate scenarios from global climate models (GCMs) based on projected amounts and timing of precipitation and increases in air temperature are widely used in climate impact assessments (Girvetz et al. 2009). One of the goals of this study is to improve our understanding of the fate of precipitation in terrestrial ecosystems in the context of both historical and projected coupled climate-hydrology assessments. The three main pathways of precipitated water in a terrestrial system include the following: (1) returning to the air via evaporation and plant transpiration; (2) infiltrating subsurface into soils and potential recharge to aquifers; and (3) flowing "overland" to create runoff that feeds the flow of stream and river channel networks. These three terms represent the primary components of an all-purpose water balance that can be customized using site-specific data on topography, soils, and geology. Quantifying the relationships and tradeoffs between these pathways provides for much more detailed projections of the impacts of variability in water availability on ecosystems and their inhabitants. Although future climate change projections are variable due to uncertainties inherent to variable emissions scenarios and the range of available GCMs, mechanistic, process-based, hydrologic modeling informed by long-term empirical (measured) data sets can constrain the functional uncertainty of GCM-based future hydrology projections.

Reducing uncertainty in future climate-hydrology scenarios can be achieved by incorporating deterministic processes and empirically confirmed landscape characteristics into estimates of potential hydrologic outcomes. Validation of spatially explicit hydrologic models that quantify the water balance by comparing measured streamflow with model output is a promising approach to defining reasonable mechanistic relationships among climate, hydrology, and the landscape. These relationships can be calibrated using a historical baseline and then can be applied to assess future climate projections (Flint and Flint 2012a). The value of such a spatially validated mechanistic model is more robust projections for runoff and other components of the water balance under future climates. Effective ecological projections and planning in the face of climate change, especially in arid climates, now demand this level of hydrologic specificity (e.g. Marcarelli et al. 2010).

The scale of information needed by land and water managers is often finer than data generated by GCMs (Littell et al. 2012). Spatial downscaling resolves climate data to a spatial grain size that can be validated using watershed-based methods, applied to local landscapes, or analyzed across large regions. Downscaling is therefore a critical first step in developing estimates of water balance components for watersheds that are robust enough for use under current or future climates.

Fluctuations in runoff and recharge across multiple watersheds can be assumed to be monotypic or else variable in response to variable precipitation: in order to minimize uncertainty, there is a need for analysts to be able to model hydrologic cycles based on nearby conditions at the watershed scale. In addition, since relatively few watersheds are gaged, physically based models of hydrologic dynamics are often required to assess landscapes. For example, for the California hydrologic region, which includes all basins that drain into the state (Figure 1), there were approximately 1,700 streamgages in operation circa 2000, with periods of record ranging from 1 to 109 years; and only 1,400

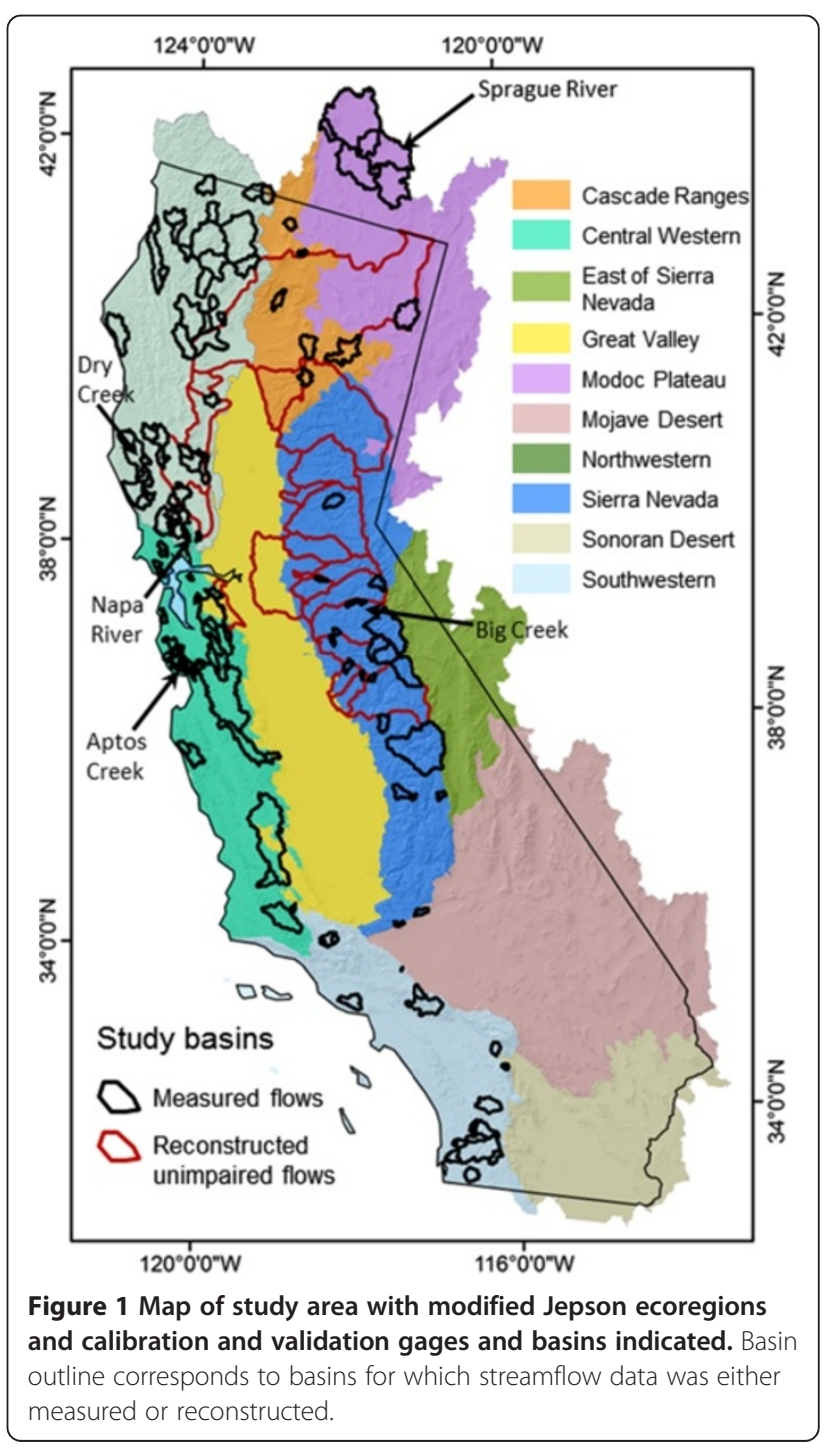


with periods of record 5 years or greater. These streamgages represent less than a third of the 5,128 subwatersheds in California (www.cain.ice.ucdavis.edu/calwater/), which is presumably one of the better instrumented regions of the world.

California's streamgage records display a wide variety of discharge dynamics, from flashy systems with high runoff peaks as a result of low permeability bedrock (such as granites in the Sierra Nevada) or large areas of impervious urban surfaces, to high baseflows with very permeable bedrock composition (e.g. volcanic rock; Flint and Flint 2007; Flint et al. 2011; Tromp-van Meerveld et al. 2007). The degree of climate aridity and soil type also affect potential hydrologic response to climate, with the deep unsaturated zones in arid regions or the deep soils of California's Central Valley storing water when available from wet climate cycles that can be used as groundwater during dry periods (Flint and Flint 2007).

The objective of this paper is to document the development of a regional scale water-balance model that rigorously incorporates deterministic processes, and describe its application to the California hydrologic region at relatively fine spatial scales. The advantages of finescale application will be discussed. The calibration and validation of this model to measured streamflow provide confidence in the application of the model to both historical and future changes in hydrology as a result of climate that are described in a companion paper (Thorne et al. 2013). Further descriptions of the datasets discussed and the post-processing and availability of files are documented in Thorne et al. (2012). Previous versions of this model and applications to small regions or basins have been previously published and include Flint and Flint (2007, 2012a), Flint et al. (2011, 2012), and Micheli et al. (2012).

\section{Hydrologic modeling background}

Many approaches to hydrologic modeling have been developed. The U.S. Geological Survey (USGS) Precipitation-Runoff Modeling System (PRMS) is used to simulate flows under future climate conditions at the watershed scale (Leavesley et al. 1992; Hay et al. 2011). This approach requires daily temperature and precipitation values that are applied to individual watersheds and used in a deterministic, distributed-parameter setting (Risley et al. 2011). The Variable Infiltration Capacity model (VIC) is a spatially explicit physical hydrology model, generally run regionally at coarse spatial scales, that balances energy and water budgets (Liang et al. 1994) and also runs using daily data (Wood et al. 2002). This model has also been applied to monthly climate in a model comparison study by Mauer et al. (2010), who found that model selection was less important for capturing high flow timing, but that for the low flows, the models tested varied, implying a need to vet model performance, particularly for aridifying regions. These rainfall-runoff models are specifically calibrated to streamgage data.

Other hydrologic modeling approaches have used streamgage data to validate the model projections using current or historical data. Alkama et al. (2011) developed the Interactions between Soil, Biosphere, and AtmosphereTotal Runoff Integrating Pathways (ISBA-TRIP) and looked at multi-decadal variability in continental runoff from 1960-1994 using 154 large rivers with different lengths of streamgage data for validation. Chiew et al. (2010) found that five different downscaling techniques all reproduced observed rainfall, and runoff models used were capable of reproducing observed streamflows for eight basins in Australia. These efforts point to the need to understand the capacity and limitations of hydrologic models that are used for future projections.

All these rainfall-runoff models rely on soil storage in some capacity yet do not incorporate bedrock properties; thus, they neglect the influence of spatially varying bedrock permeability in estimates of recharge. Experimental evaluations of hillslope processes include a few that have investigated the influence of bedrock permeability on hydrologic response to climate (Hutchinson and Moore 2000; Tromp-van Meerveld et al. 2007), while a few others numerically modeled watersheds including bedrock properties (Flint and Flint 2006; Jones et al. 2008; Hopp and McDonnell 2009). Generally, these models are two- or three-dimensional, finite-element models that explicitly incorporate bedrock but are computationally intensive and cover small areas. Historically, recharge estimates have relied on monthly water balance models that incorporate simulations of evapotranspiration (Alley 1984), inverse modeling (Sanford et al. 2001), or lysimetry and tracer tests (Gee and Hillel 1988). Waterbalance modeling to assess both recharge and runoff has been done at the site scale (Flint et al. 2002a; Ragab 1996) and integrated with various measurements addressing different spatial scales (Flint et al. 2002b). Watershedscale or regional-scale modeling to estimate recharge and runoff has been done using water-balance modeling by Hevesi et al. (2003), Flint et al. (2011), and Flint and Flint (2007).

\section{Evaluating hydrologic response to climate in California}

We used the Basin Characterization Model (BCM) to model the hydrologic cycle for the California hydrologic region [Figure 1; modified from Hickman (1993)]. This paper presents results for two 30-year periods from 1951-2010 for all watersheds and by ecoregion for precipitation, air temperature, April 1st snowpack, recharge, runoff, potential evapotranspiration (PET), actual evapotranspiration, and climatic water deficit, a parameter 
that is a function of PET and actual evapotranspiration (Stephenson 1998).

To develop confidence in the application of the model this paper also evaluates the reliability of hydrologic model performance by comparing basin discharge, a product of the runoff and recharge values generated by the $\mathrm{BCM}$ with streamgage data. Historical streamgage data were assembled from 138 mostly unimpaired basins (Figure 1), along with reconstructed unimpaired flows from 21 additional basins, and monthly and yearly summaries from streamgages were used to test how well the BCM model outputs perform on watersheds with varying bedrock permeability, soil properties, impermeable surfaces, and degrees of aridity. The results of this model testing permit hydrologic simulation performance within the study area due to influences of landscape variables.

\section{Description of the Basin Characterization Model (BCM)}

The Basin Characterization Model (BCM) is a regional water balance model (Flint and Flint 2007;
Thorne et al. 2012). The BCM (Figure 2) mechanistically models the pathways of precipitation into evapotranspiration, infiltration into soils, runoff, or percolation below the root zone to recharge groundwater. The evapotranspiration component is derived through the use of PET equations (Priestley and Taylor 1972) that rely on the calculation of solar radiation using slope, aspect, topographic shading, and atmospheric parameters. For the purposes of comparison across watersheds (or other landscape units), PET in the BCM is not interactive with the other segments. In other words, potential water demand from plants is independent from other hydrodynamic components in the model. The soil storage component of the model uses soil properties to calculate how much soil moisture is available for plant evapotranspiration. Soil storage is also independent from the other hydrologic dynamics, except that groundwater recharge, calculated as infiltration below the zone of evapotranspiration, is calculated only from surplus, after soil moisture capacity has been filled. Groundwater recharge (recharge) is also tied to runoff, and the

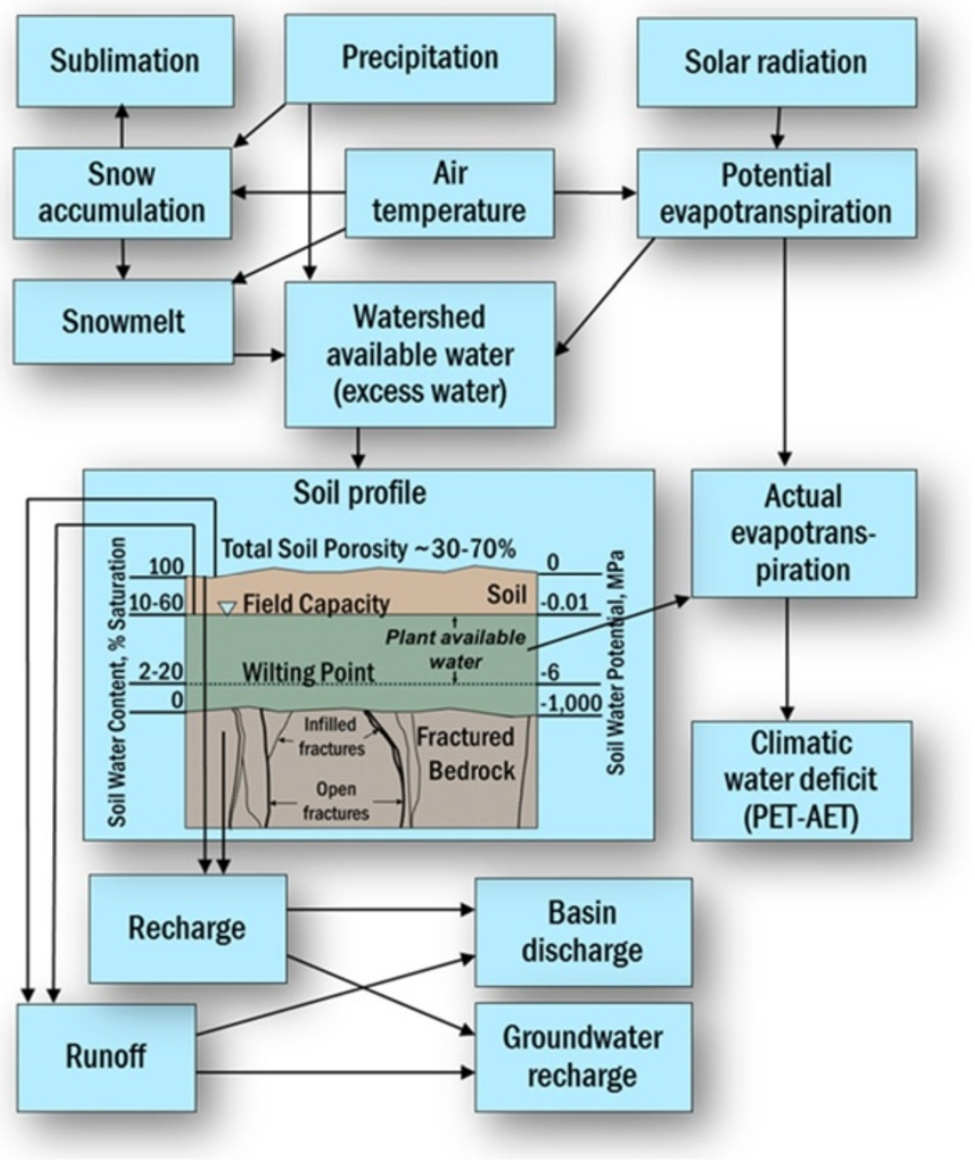

Figure 2 Schematic describing relation of components of the Basin Characterization Model. 
relationship between the two is driven by the level of permeability of bedrock.

Therefore, the BCM can model the response of any given watershed to climate as driven by its energy balance (based on latitude, longitude, elevation, slope, and aspect), soil moisture storage capacity, and the characteristics of the materials that are deeper than the rooting zone, including deep alluvial valleys or bedrock that can permit percolation into groundwater. The BCM calculates hydrologic variables on a grid cell basis and can be run at any spatial resolution, generally limited by data resolution, computing power, or file storage capabilities. Grid cell values can be summarized for any spatial pattern, such as watersheds. A post-model calculation for basin discharge can be performed.

The BCM has several subroutines or modules: the calculation of potential and actual evapotranspiration and climatic water deficit; snow accumulation and melt; available water; and recharge and runoff (Figure 2). The model begins with climatic inputs of precipitation and air temperature. This is followed by the calculation of PET, which relies on an hourly energy-balance calculation, based on solar radiation, air temperature, and the Priestley-Taylor equation (Flint and Childs 1991). Clear sky PET is calculated using a solar radiation model that incorporates seasonal atmospheric transmissivity with site parameters of slope, aspect, and topographic shading (to define the percentage of sky seen for every grid cell) (Flint and Childs 1987). Hourly PET is aggregated into monthly time series, and cloudiness corrections are made on the basis of calibrations using cloudiness data from National Renewable Energy Laboratory (NREL; http://www.nrel.gov/; Flint and Flint 2008). Modeled PET for the southwest United States has been calibrated to measured PET from California Irrigation Management Information System (CIMIS) and Arizona Meteorological Network (AZMET) stations (Flint and Flint 2007).

Using PET and gridded precipitation, maximum and minimum air temperature, and the approach of the National Weather Service Snow-17 model (Anderson 1976), the snow module accumulates, sublimates, and melts snow to produce available water (Figure 2). These inputs to the water balance have been calibrated regionally to solar radiation and PET data, and snow cover estimates have been compared to Moderate Resolution Imaging Spectroradiometer (MODIS) snow cover maps (Flint and Flint 2007). This paper presents further snow module calibration work.

The BCM's available water calculation quantifies water that is available for use in the remaining parts of the BCM, which balance watershed hydrologic components (Figure 2). Available water occupies the soil profile, where it will become actual evapotranspiration (AET), and may also result in runoff or recharge, depending on the soil storage and permeability of the underlying bedrock. Total soil-water storage is calculated as porosity multiplied by soil depth. Field capacity [soil water volume at -0.03 megapascals $(\mathrm{MPa})]$ is the soil water volume below which gravity drainage is negligible, and wilting point (soil water volume at $-1.5 \mathrm{MPa}$ ) is the soil water volume below which actual evapotranspiration does not occur (Hillel 1980). Once available water is calculated, it may exceed total soil storage and become runoff, or it may be less than total soil storage but greater than field capacity and become recharge. Anything less than field capacity is calculated as AET, at the rate of PET for that month, until it reaches wilting point. This permits the subsequent calculation of climatic water deficit (CWD).

When soil water is less than total soil storage and greater than field capacity, soil water greater than field capacity equals recharge. If recharge is greater than bedrock permeability $(K)$, then recharge $=K$ and excess becomes runoff, else it will recharge at $\mathrm{K}$ until field capacity is reached. Runoff and recharge are combined to calculate basin discharge, and actual evapotranspiration is subtracted from PET to calculate CWD.

The BCM can be used to identify locations and climatic conditions that generate excess water by quantifying the amount of water available either as runoff generated throughout a basin or as in-place recharge (Flint and Flint 2007). Because of the grid-based, simplified nature of the model, with no internal streamflow routing, long time series for very large areas can be simulated easily. However, if local unimpaired streamflow data are available, estimated recharge and runoff from each grid cell can be used to calculate basin discharge that can be extrapolated through time for varying climates. In addition, the application of the model across landscapes allows for grid-based comparisons between different areas. Because of the modular and mechanistic approach used by the BCM, it is flexible with respect to incorporating new input data or updating of algorithms should better calculations be derived. All input files necessary to operate the $\mathrm{BCM}$, and the output files resulting from the simulations, are shown in Thorne et al. (2012; Appendix A). A complete list of all input and output variables and definitions is included in Thorne et al. (2012; Appendix B).

\section{Methods}

This paper presents the development and calculation used in the BCM for PET, snow, AET recharge, runoff, and climatic water deficit. We characterize the results for a 30-year period from 1981-2010, and changes from 1951-1980, and assess model performance for the runoff and snow modules by using streamgages and snow courses. 


\section{Model development}

All climate grids and maps of properties require the same grid scale, in this case $270 \mathrm{~m}$, for model operation. The historical PRISM precipitation and temperature data (Daly et al. 2008) were spatially downscaled from $800 \mathrm{~m}$ to $270 \mathrm{~m}$ using Gradient-Inverse-Distance-Squared (GIDS) downscaling (Nalder and Weins 1998). The approach applies a spatial GIDS weighting to monthly point data by developing multiple regressions for every fine-resolution grid cell for every month. Using the PRISM climate variables and a 270-m-resolution digital elevation model, parameter weighting is based on the location and elevation of the coarse-resolution cells surrounding each fine-resolution cell to predict the climate variable of the fine-resolution cell (Flint and Flint 2012b; modified from Nalder and Weins 1998). To remove the "bulls-eye" effect often associated with certain interpolation schemes (e.g., kriging, inverse distance squared), the program was modified to have a search radius that is specified as the size of grid cell of the coarse-resolution grid. The modified GIDS spatial downscaling technique does not introduce additional uncertainty in the downscaling process and may indeed improve the estimate of the climate variable by incorporating the deterministic in- fluence (such as lapse rates or rain shadows) of location and elevation on climate (Flint and Flint 2012b).

The climate surfaces and monthly PET were combined with maps of elevation, bedrock permeability (K) estimated on the basis of geology (Figure 3) (Jennings 1977), and water content at field capacity and wilting point, porosity and depth from SSURGO soil databases (NRCS 2006). Available soil-water storage, shown in Figure 4, is calculated as water content at field capacity minus water content at wilting point multiplied by soil depth.

Climatic water deficit (CWD) integrates energy loading and moisture availability from precipitation with available soil water. CWD is calculated as PET minus AET, and the actual evapotranspiration is calculated on the basis of the loss of available soil water throughout the water year. CWD is generally accumulated annually. The distribution of moisture conditions that define the amount of water in the soil that can be maintained for plant use throughout the growing season and summer dry season corresponds very well to the established distribution of vegetation types. However, in many locations shallow soils limit the contribution of precipitation.
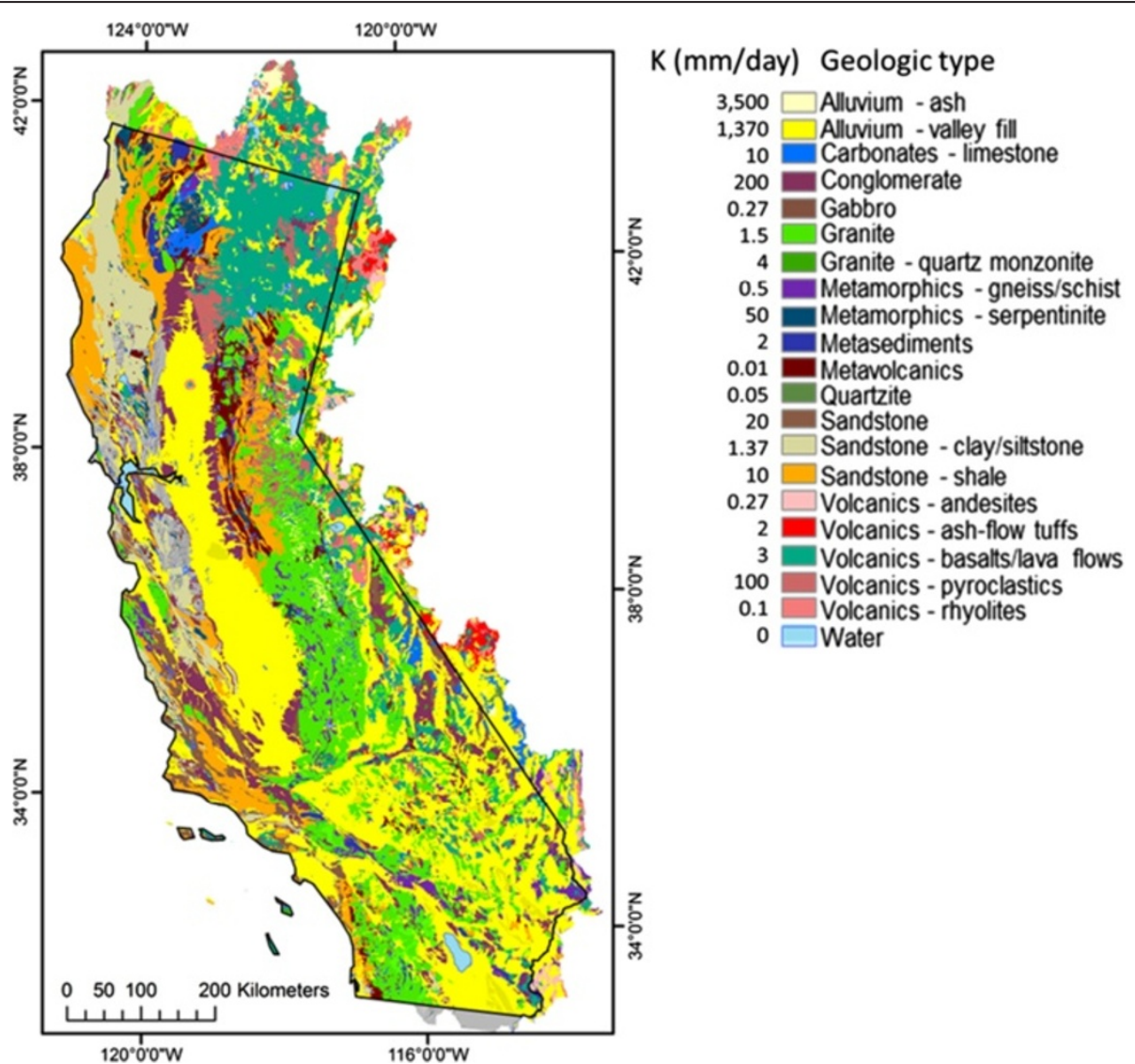

Fure 3 Map of geology for study area with estimated bedrock permeability. 


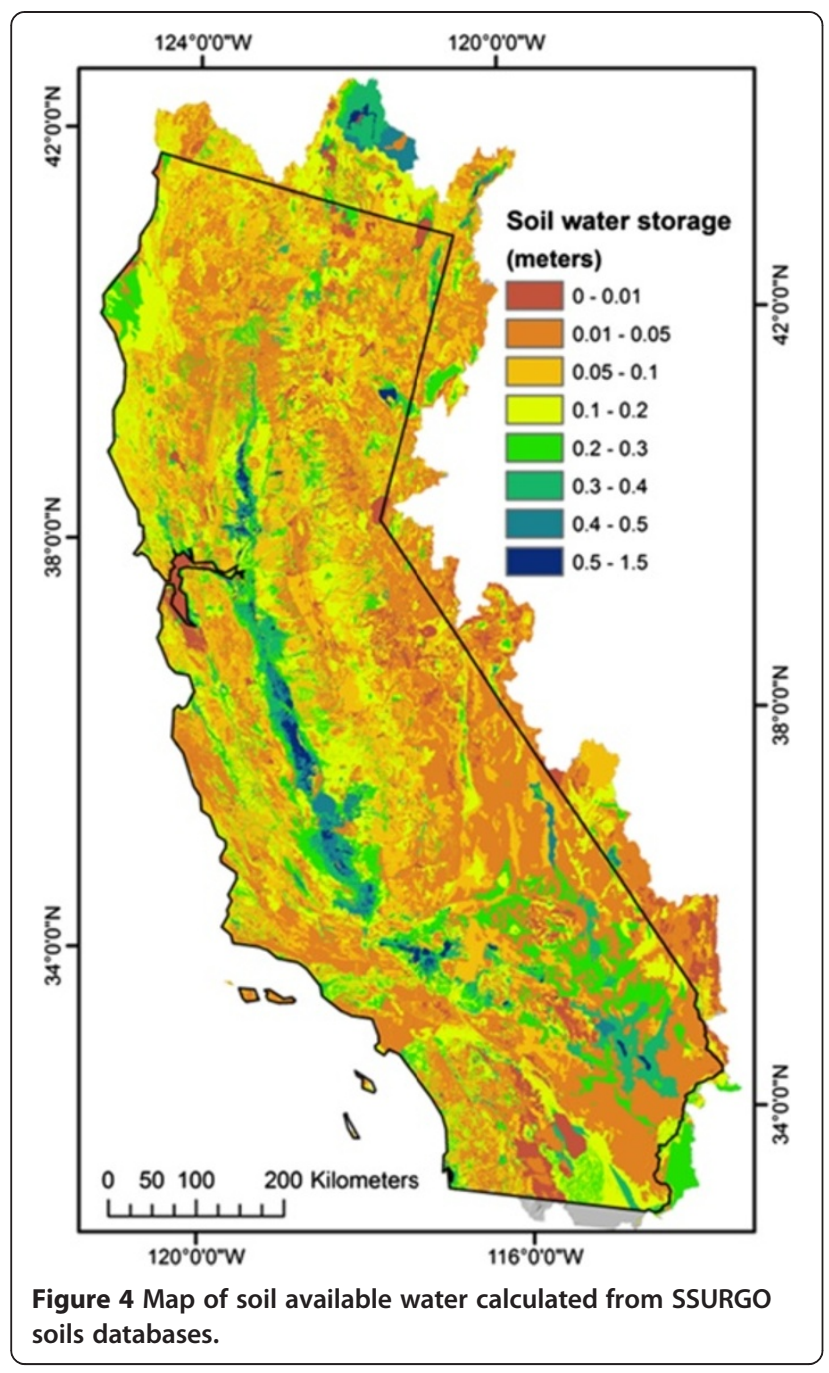

Average annual hydrologic derivatives of runoff, recharge, and CWD were analyzed for current climatic conditions, represented as 1981-2010. An analysis of change between current climatic conditions and historical baseline (1951-1980) is also discussed for snowpack and the ecologically important variable, CWD.

\section{Model calibration, routing, and performance}

The CA-BCM was applied to the entire California region to provide hydrologic response to current climate using previous regional calibrations for solar radiation, PET, snow cover, and groundwater (Flint and Flint 2007; Flint et al. 2011), and a series of 159 watersheds (basins; Figure 1) were selected for calibration and validation purposes to provide runoff and recharge for current climatic conditions. Additional calibration of the snow module was done for California using snow course data in the Sierra Nevada and Trinity Mountains, MODIS snow cover data, and mapped glaciers. To ensure correct timing of snow accumulation and melt on a volume basis, calibration of the snow module was done to compare average monthly flows from the CA-BCM to unimpaired flows to the Central Valley for 21 basins that were based on reconstructions (see DWR 2007 for methodology). Recharge and runoff were calculated for all grid cells. Recharge and runoff estimated by the CA-BCM was used with post-processing equations, described later, to calculate basin discharge for 159 basins for which we also had streamflow time series, including measured streamflow from National Water Information System (NWIS) and reconstructed unimpaired flows from the California Department of Water Resources (DWR 2007).

Generally the basins used for calibration were selected on the basis of lack of impairments, such as urbanization, agriculture, reservoirs, or diversions. This information was obtained using land use/land cover maps or NWIS. Gages located downstream of obvious urban or agricultural areas (areas where more than approximately $30 \%$ of the area is mapped as urban or agricultural) were not used for calibration because of the additional water use or return flows that are unrepresentative of the water-balance calculations done using the BCM. We also sought to use streamgages with periods of record that extended across several years to capture the influences of climate variability. However, applications in some basins (either highly impaired or with very few gages) required use of streamflow data that reflected impairments or had relatively short periods of record.

We used 68 basins for calibration, which was done by iteratively adjusting the estimates of bedrock permeability to optimize the match between calculated basin discharge and measured historical streamflow. This was done to alter the proportion of excess water that becomes recharge or runoff. This is iterative among all calibration basins because the geologic units are mapped across the entire state, and if the permeability is changed to optimize the fit in one basin it changes the permeability wherever the geology is mapped. Calibration basins represent 9 of the 14 dominant geologic types, and have been calibrated to bedrock permeability on the basis of mapped geology for California (Figure 3). This part of the calibration process is followed by accounting for stream channel gains and losses to calculate basin discharge and optimize the fit between total measured volume and simulated volume for the period of record for each gage. The equations are used to calculate surface-water flow recession, seepage, and baseflow that can extend throughout the dry season.

In order to evaluate the CA-BCM effectiveness in estimating hydrologic conditions across California, once the model was calibrated using the 68 calibration basins, we used an independent set of 91 validation basins to compare estimated results generated using the calibrated model. Basin discharge was calculated for validation 
basins without the adjustment of bedrock permeability to improve matches to measured data. This comparative analysis provides a measure of model performance based on the ability of the CA-BCM to accurately estimate basin discharge. Since the basin discharge estimates for validation basins were developed using the bedrock permeability values developed and adjusted during the calibration phase, this method tests how well these permeability estimates work when extrapolated across the entire state. The statistics were developed following the same procedure as the calibration basins to achieve an exact match between measured and simulated volumes for the period of record of the streamgage. See Additional file 1 for descriptions of 159 calibration and validation basins, equation coefficients, and goodness-of-fit statistics.

\section{Procedure for calculating basin discharge}

As described, the CA-BCM simulates recharge $\left(B C M_{\text {rch }}\right)$ and runoff $\left(B C M_{\text {run }}\right)$ for each 270 -m grid cell for each month (i). To compare them to gaged mean monthly streamflow, all grid cells upstream of the streamgage are summed for each month to create time series for $B C M_{\text {run }}$ and $B C M_{\text {rch }}$. To transform these results into a form that can be compared to the pattern and amount of gaged streamflow, the water balance is conceptualized as consisting of three groundwater reservoirs that are hydraulically connected (Figure 5). This conceptualization has been refined since the publication of an earlier version of BCM (Thorne et al. 2012; Flint et al. 2012). The surface reservoir (1) consists of all the surface and near surface processes, such as runoff and seepage, that hold and direct water toward the stream and that are event driven $\left(G W_{\text {surface( } i)}\right)$. The shallow groundwater reservoir (2) consists of the shallow transient saturated zone that rises and falls seasonally providing much of the baseflow, but can sometimes also be event driven, and provides some recession flow $\left(G W_{\text {shallow }(i)}\right)$. The deep groundwater reservoir (3) is the regional aquifer but can also provide some flow to the shallow groundwater reservoir $\left(G W_{\operatorname{deep}(i)}\right)$ over long time frames.

A set of empirical discharge equations defines storage in successive time-steps $(i)$ and performs partitioning. $G W_{\text {shallow(i) }}$ is the computational method used to extend streamflow for time-steps when $B C M_{\operatorname{run}(i)}$ and $B C M_{\operatorname{rch}(i)}$ are zero (e.g. during seasonal and annual dry periods). For time-steps when $B C M_{\mathrm{run}(i)}$ and $B C M_{\mathrm{rch}(i)}$ are nonzero, the amounts are accumulated for the grid cells upstream of a streamgage and are compartmentalized into the surface and subsurface reservoirs.

$G W_{\text {surface }(i)}$ is evaluated as:

$$
\begin{aligned}
G W_{\text {surface }(i)}= & G W_{\text {surface }(i-1)} \\
& +B_{\text {run }(i)}-\text { Surfaceflow }_{(i-1)}
\end{aligned}
$$

where the current month's streamflow Surfaceflow $(i)$ is:

$$
\text { Surfaceflow }(i)=\left(\text { SurfaceScaler } * G W_{\text {surface }(i)}\right)^{\text {SurfaceExp }}
$$

and SurfaceScaler and SurfaceExp are coefficients that are used to match peak and recessional flows. Typically these coefficients are $\leq 1$, but in some cases precipitation data can underrepresent localized peak events and SurfaceScaler may exceed 1 to account for precipitation errors and match peak flows.

$G W_{\text {shallow }(i)}$ is evaluated as:

$$
\begin{aligned}
G W_{\text {shallow }(i)}= & G W_{\text {shallow }(i-1)} \\
& + \text { BCM }_{r c h(i)}-\text { shallowflow }_{(i)}-\operatorname{deepflow~}_{(i)}
\end{aligned}
$$

where

$$
\text { Shallowflow }(i)=\left(\text { ShallowScaler } * G W_{\text {shallow }(i-1)}\right) \text { ShallowExp }
$$

and ShallowScaler and ShallowExp are coefficients $(\leq 1)$ that are used to match base flow and longer term

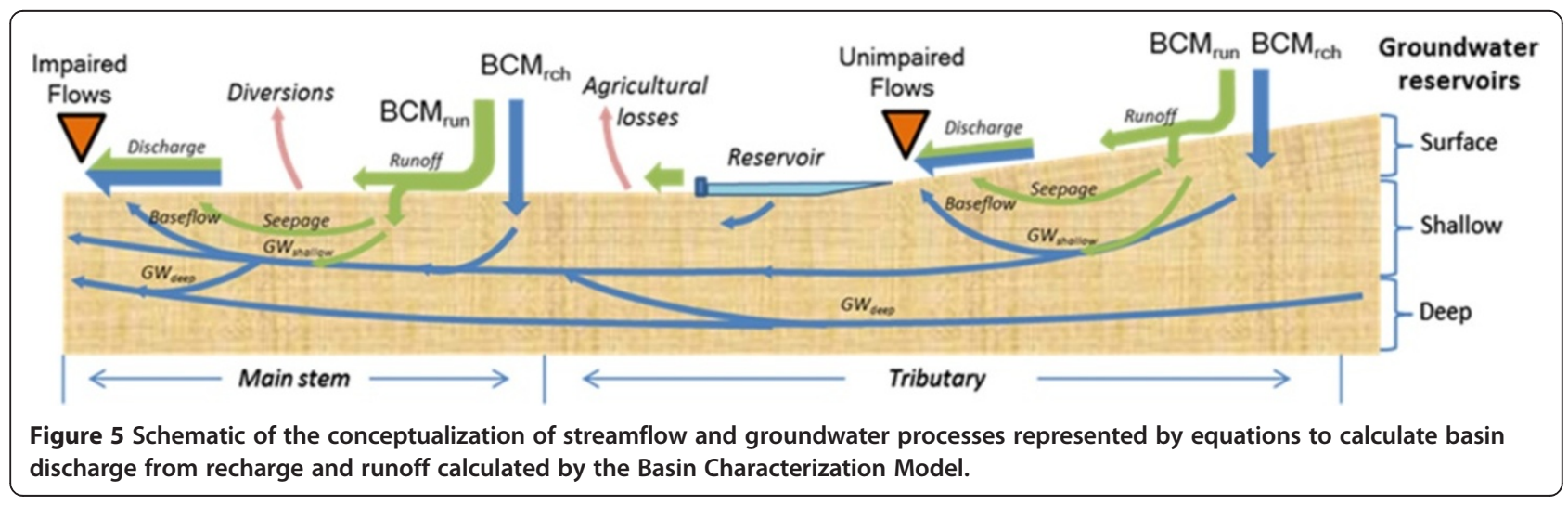


recessional flows, and

$$
\operatorname{Deepflow}(i)=\left(\text { DeepScaler } * G W_{\text {shallow }(i-1)}\right)^{\text {DeepExp }}
$$

and is water subtracted from the shallow reservoir to simulate deep groundwater recharge and DeepScaler and DeepExp are coefficients $(\leq 1)$ that are used to help maintain mass balance between the measured streamflow and simulated streamflow by limiting the contribution of the shallow groundwater reservoir to streamflow.

Streamflow within the basin (upstream of the streamgage: $\left.\operatorname{Stream}_{(i)}\right)$ is calculated by summing the contribution from the surface and shallow reservoirs:

$$
\operatorname{Stream}_{(i)}=\text { Surfaceflow }_{(i)}+\text { Shallowflow }_{(i)}
$$

Finally, basin discharge $\left(\right.$ Discharge $\left._{(i)}\right)$ is calculated as:

$$
\operatorname{Discharge}_{(i)}=\text { WatBal } * \operatorname{Stream}_{(i)}
$$

where WatBal is a coefficient $(>1$ or $\leq 1)$ used to maintain a water balance between the simulated basin discharge and the streamgage data or unimpaired flow estimates and simulates gaining $(>1)$ or losing $(<1)$ streams within the basin over the longer term (tens of years). This coefficient may also account for impairments to the basin that impact the stream as well. While $\operatorname{Rch}_{(i)}$ and $\operatorname{Run}_{(i)}$ are calculated by the BCM, all the other components used to calculate Discharge $_{(i)}$ are the post-processed portion of the BCM water balance that is compared to the pattern and amount of gaged streamflow.

$B C M_{\text {rch }}$ and $B C M_{\text {run }}$ reflect natural hydrologic conditions and do not account for diversions, reservoir storage or releases, urban runoff, groundwater pumping, or other impairments, and therefore will not exactly match measured streamflow in impaired basins.

\section{Results}

Study basins used for calibration and validation are generally representative of the range of elevations of the 5,120 basins modeled for the California region (see Thorne et al., Figure 4), with decreasing representation at higher elevations. Bedrock permeability due to underlying geology is dominated by lower permeability basins because very high permeability basins, such as those with alluvial valley fill, do not generally generate enough stream flow to be captured using streamgages. Similarly, the range of climates in the state is not well represented by the set of study calibration basins due to poorer representation of desert regions with their lack of streamflow data. The range of ecoregions represented by study basins also reflects the lack of unimpaired streamgage data in the desert areas, the eastern side of the Sierra Nevada, and the deep soils of the Central Valley (Great Valley).

\section{BCM calibration and performance}

The application of the BCM to simulate unimpaired hydrologic conditions across the entire state relies on the thoroughness of the calibration to geology and the effectiveness of matching estimated basin discharge to corresponding measured streamflow. Calibration statistics (Additional file 1) include the linear regression $r^{2}$ for comparisons of monthly and yearly measured versus simulated basin discharge and the Nash-Sutcliffe efficiency statistic (E; Nash and Sutcliffe 1970). E is calculated as 1 minus the ratio of the mean square error to the variance. The $r^{2}$ statistic is useful as a comparative statistic as suggested by Legates and McCabe (1999), whereas the $\mathrm{E}$ value provides perhaps a better representation of goodness-of-fit. E is widely used to evaluate the performance of hydrologic models and has been shown to be sensitive to differences in the observed versus modeled simulated means and variances but also can be overly sensitive to extreme values, as can also be the case for $r^{2}$ (Legates and McCabe 1999). E ranges from negative infinity to 1 with higher values indicating better agreement. Statistics calculated for the 159 basins are shown in the Additional file 1, with values slightly higher for calibration basins than validation basins. Average goodness-of-fit statistics for all the basins (calibration plus validation) are $\mathrm{E}=0.67$, monthly $\mathrm{r}^{2}=$ 0.73 and yearly $r^{2}=0.82$. ShallowScaler and DeepScaler coefficients were 1.00 for all basins in this dataset and are omitted from the Additional file 1.

For some basins it was necessary to adjust the SurfaceScaler coefficient to match peak flows, and the average coefficient is greater than 1.0, suggesting that the monthly precipitation data do not accurately reflect the maximum precipitation within some basins. The average SurfaceExp coefficient controls the shape of the seasonal recession curve, and the averages for all the calibration basins were the same, 0.97, with higher values resulting in a steeper recession curve and lower values indicating a slower recession. The ShallowExp coefficient controls the annual recession and summer baseflows, with an average of 0.55 , and the DeepExp coefficient allows for the match of multi-year changes in baseflows, with an average of 0.58. If there is little recharge calculated by the BCM, the DeepExp coefficient is insensitive to adjustment.

The timing of snow accumulation and melt is an important feature to capture correctly because of the importance of the snowpack to California water resources. Details shown in Curtis et al. (in review) illustrate goodness-of-fit to the presence of glaciers, and accumulation and melt using maps of remotely sensed snow cover. The comparisons to measured snow water equivalent were 
generally within $0.3 \mathrm{~m}$ for 45 snow courses. Visual comparisons of snow accumulation with January and February snow cover data and snowmelt with April and May snow cover data indicated good fits (Curtis et al. in review). The calibration of snow module parameters was done to optimize the discharge estimated by the CA-BCM in comparison to reconstructed unimpaired flows for 21 mountain basins draining to the San Francisco Bay Delta (Figure 1). Average monthly $\mathrm{r}^{2}$ for reconstructed unimpaired flows versus BCM-estimated flows for water years $1996-2005$ was 0.76 , yearly $r^{2}$ was 0.91 , and $E$ was 0.69 . The discrepancies between monthly and yearly $\mathrm{r}^{2}$ represent a mismatch in monthly timing for these large basins with long surface water and groundwater travel times, which is not shown in the yearly $\mathrm{r}^{2}$ calculation. The average $\mathrm{r}^{2}$ for the comparison of the reconstructed and BCM-estimates of average flow for 1996-2005 for each month, which indicates how well the BCM represents the timing of snow processes, was 0.91, indicating an excellent match in the timing of monthly discharge. The poorest fits were for the Sacramento River near Red Bluff and the Feather River near Oroville (0.57 and 0.71, respectively), while the best fits were the major watersupplying basins in the southern Sierra Nevada $\left(r^{2}=0.94-\right.$ 0.98; Tuolumne, Merced, San Joaquin, Kings, and Kaweah river basins).

Calibration basins evaluated alone have a mean $\mathrm{E}$ of 0.73 , and generally, basins with the least impairments had the best calibrations. Sample calibrations are compared for Dry Creek near Cloverdale in the Russian River basin, Napa River near Calistoga in the North Bay, Big Creek above Pine Flat Reservoir near Trimmer, in the Kings River basin in the southern Sierra Nevada, Aptos Creek at Aptos in the Santa Cruz mountains, and Sprague River near Beatty, OR, in the upper Klamath River (Figure 6). Dry Creek, Napa River, and Big Creek all have moderate base flows, but based on our estimates Dry Creek loses $45 \%$ of both estimated unimpaired runoff and recharge to the groundwater system, while the Napa River is gaining from the groundwater system. Big Creek, located in granitic geology towards the lower elevations of the Kings River basin, is also a gaining stream.

Our hypothesis is that the model fits less well where there are many urban impacts that cannot be fully taken into account by the CA-BCM. There are several cases where urbanization and agriculture impacted the calibration, such as for Aptos Creek at Aptos (Figure 6d), and where urbanization resulted in very high peak flows as a result of impermeable urban areas enhancing runoff, both during precipitation events where there is reduced infiltration, and during the summer when urban runoff is enhanced, neither of which is taken into account in the CA-BCM. An example of the impact of diversions and groundwater pumping for public use on measured discharge values can be seen in the difference between the Merced River at Happy Isles, upstream of Yosemite Village, and the Merced River at Pohono, downstream of Yosemite Village, where the percentage of runoff needs to be reduced to $45 \%$ to match measured flows (Additional file 1).

The mean $\mathrm{E}$ for validation basins evaluated alone is 0.59 (0.69 for basins with reconstructed unimpaired flows), with the upper Klamath and small basins in the Modoc Plateau volcanics performing the poorest (Sprague River near Beatty OR E $=0.35$; Figure 6e). This is likely due to the large groundwater reservoir in the volcanics that has very long travel times from precipitation input to outflow in streams. The Sprague River basin also has a large agricultural component and return flows, so any attempt during calibration to maintain a match in volumes results in an overestimate of the peak flows. The presence of a groundwater reservoir also shows in the differences between the $\mathrm{r}^{2}$ values for the monthly and yearly values ( 0.36 versus 0.82 , respectively), which indicate if there are lags in the monthly calibration between measured and simulated flows that are negated when calculated yearly.

\section{CA-BCM climate and hydrology}

Our study summarizes the following estimates generated by the CA-BCM: precipitation, air temperature, PET, actual evapotranspiration, snow water equivalent (SWE), runoff, recharge, and climatic water deficit for the 19812010 time period and also evaluates change in comparison to the 1951-1980 time period.

Climate has been variable over time with general increases in precipitation, excepting northwestern CA and the Modoc Plateau, and increases in air temperature throughout the state by up to $1^{\circ} \mathrm{C}$. As a result PET has increased throughout the state by about 3\% (Table 1). Recharge and runoff have changed corresponding to changes in precipitation, and climatic water deficit has gone up in most ecoregions.

The hydrologic response to climate variability experienced from 1981 to 2010 is shown by responses in runoff and recharge for California (Figure 7). Average annual runoff and recharge are highest in locations with the greatest estimated excess water, generally in locations where annual snowpack is highest, such as in the Sierra Nevada and Trinity Mountains. Spatial patterns of runoff and recharge differ based on variability in bedrock permeability and potential soil storage. However, in locations with similar bedrock permeability, seasonal climate patterns are what dictate whether excess water becomes runoff or recharge. For example, locations on the North coast dominated by sandstones have bedrock permeabilities similar to those of the granites in the southern Sierra Nevada, yet the resulting hydrology is quite 
(a)

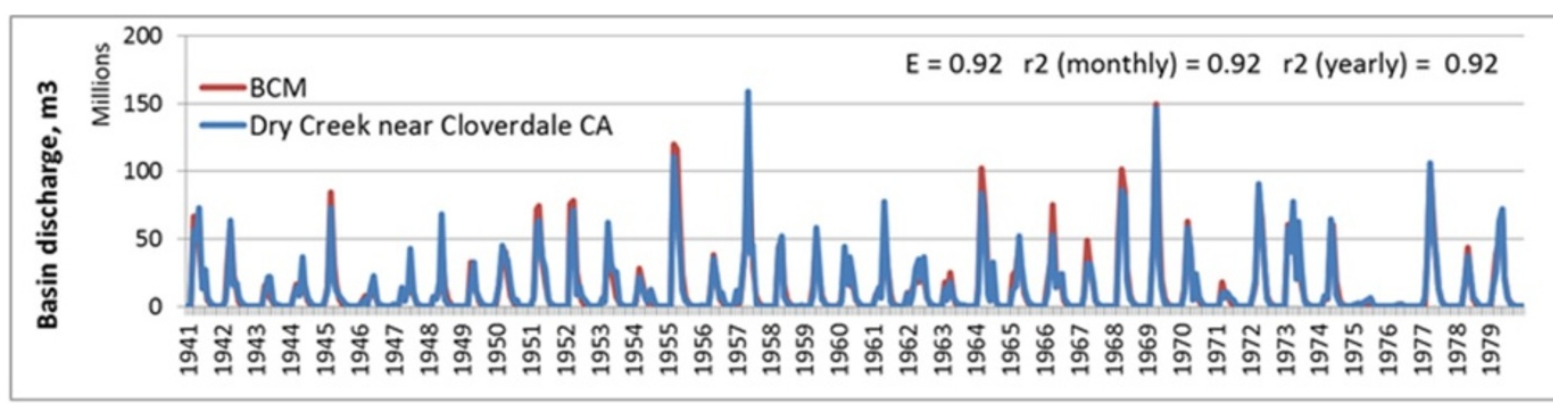

(b)

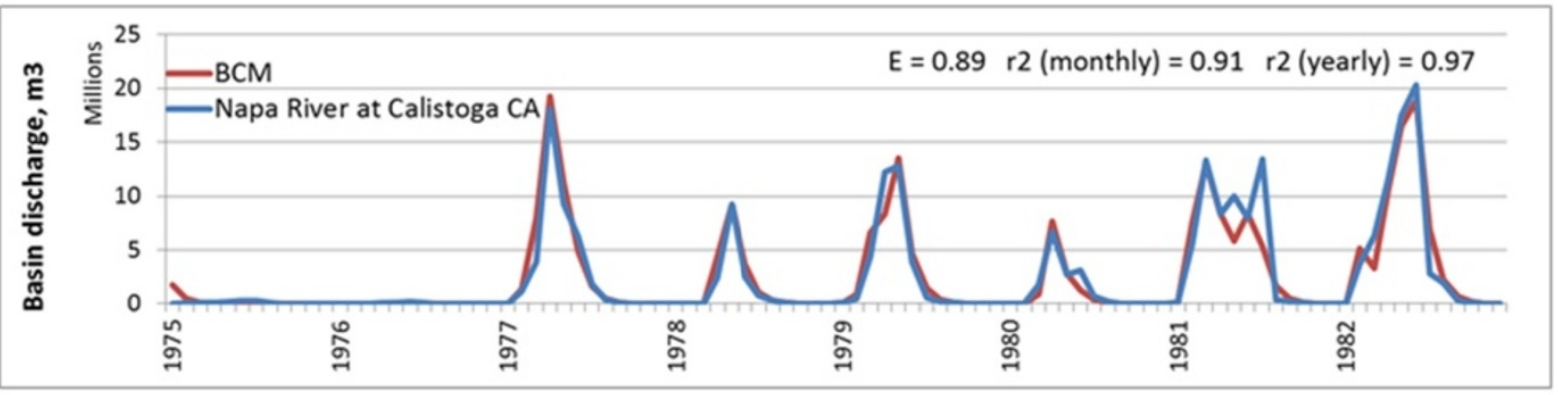

(c)

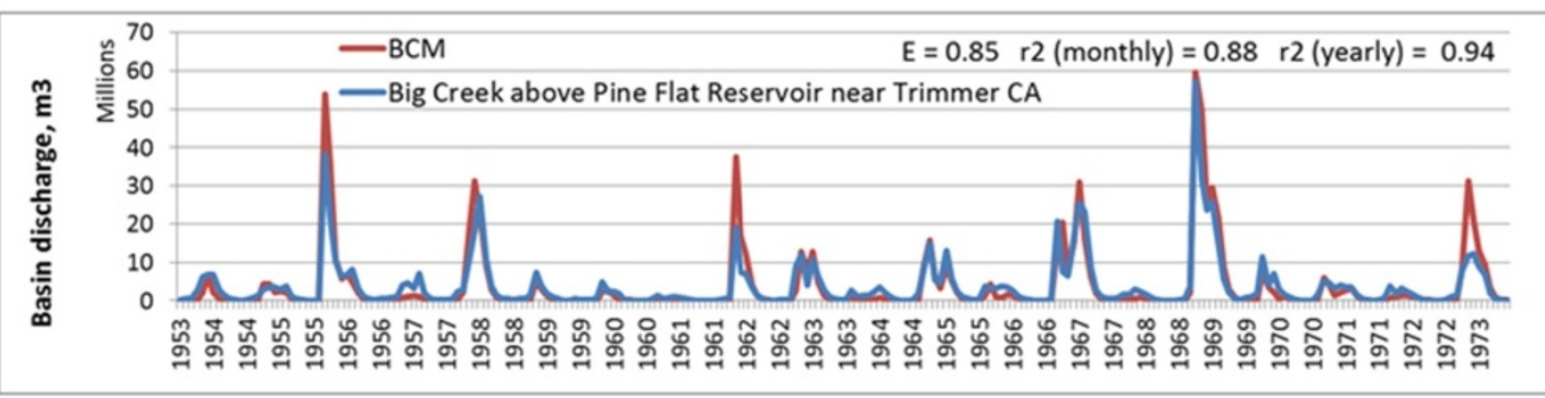

(d)

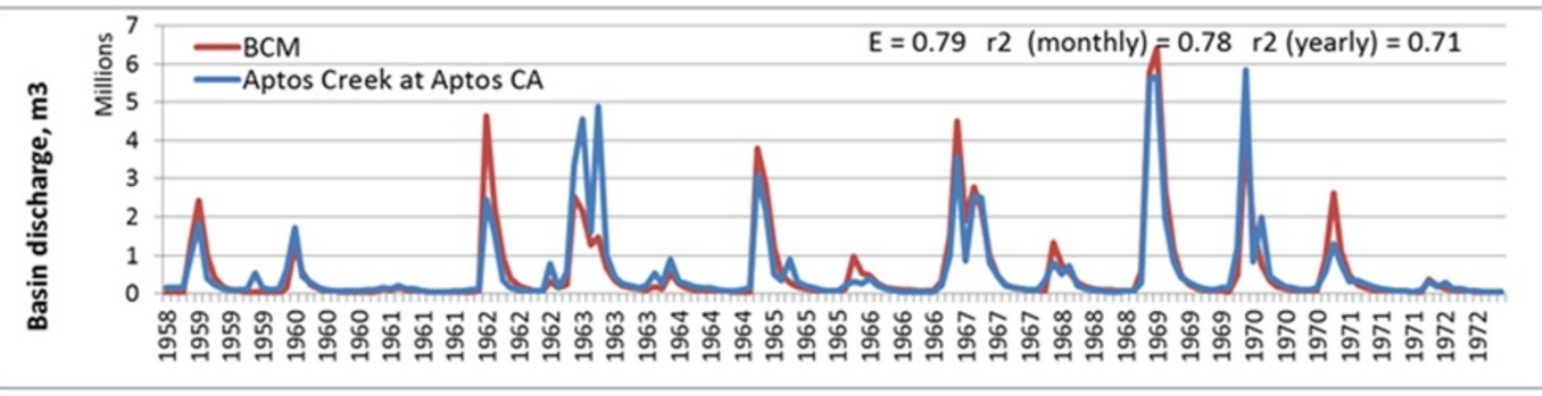

(e)

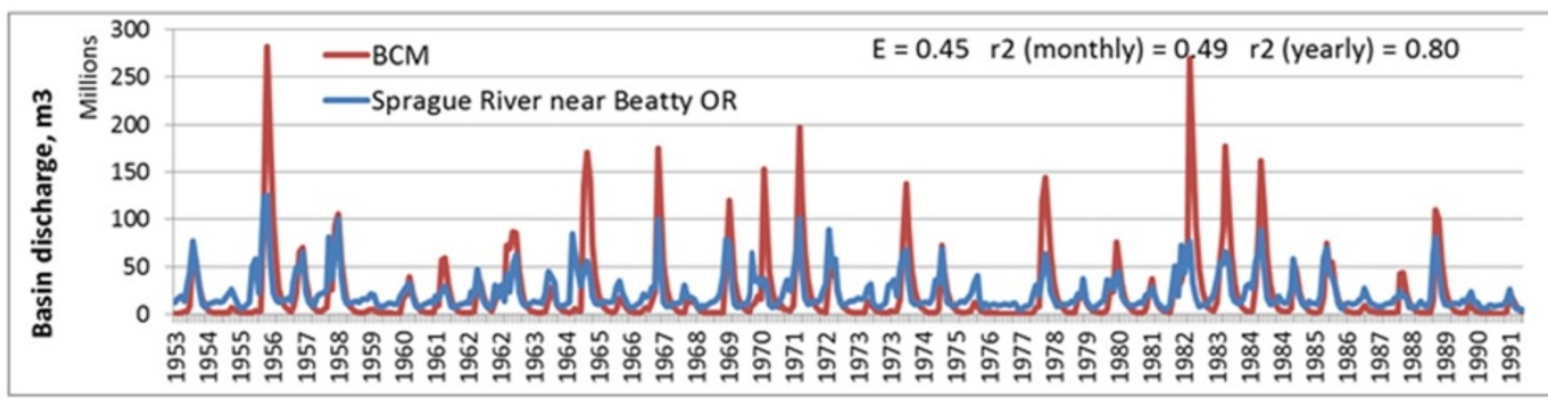

Figure 6 Calibration time series comparing measured and estimated basin discharge in millions of cubic meters, for five calibration basins: (a) Dry Creek near Cloverdale, CA, (b) Napa River at Calistoga, CA, (c) Big Creek above Pine Flat Reservoir near Trimmer, CA, (d) Aptos Creek at Aptos, CA, and (e) Sprague River near Beatty, OR. Calibration statistics, Nash-Sutcliffe efficiency tatistic (E), and monthly r2 are included. 
Table 1 Climate and hydrologic variables for modified Jepson ecoregions in California

\begin{tabular}{|c|c|c|c|c|c|c|c|c|c|c|c|}
\hline & & $\begin{array}{l}\text { North- } \\
\text { western CA }\end{array}$ & $\begin{array}{l}\text { Cascade } \\
\text { ranges }\end{array}$ & $\begin{array}{l}\text { Modoc } \\
\text { plateau }\end{array}$ & $\begin{array}{l}\text { Central } \\
\text { western CA }\end{array}$ & $\begin{array}{l}\text { Great } \\
\text { Valley }\end{array}$ & $\begin{array}{l}\text { Sierra } \\
\text { Nevada }\end{array}$ & $\begin{array}{l}\text { East of Sierra } \\
\text { Nevada }\end{array}$ & $\begin{array}{l}\text { South- } \\
\text { western CA }\end{array}$ & $\begin{array}{l}\text { Mojave } \\
\text { Desert }\end{array}$ & $\begin{array}{l}\text { Sonoran } \\
\text { Desert } \\
\end{array}$ \\
\hline \multirow[t]{3}{*}{ Precipitation (mm) } & Mean & 1,467 & 1,120 & 435 & 593 & 341 & 955 & 309 & 466 & 155 & 114 \\
\hline & Change & -33.4 & 9.5 & -1.7 & 28.2 & 24.5 & 15.6 & 23.4 & 2.5 & 13.6 & 12.9 \\
\hline & \% Change & $-2 \%$ & $1 \%$ & $0 \%$ & $5 \%$ & $8 \%$ & $2 \%$ & $8 \%$ & $1 \%$ & $10 \%$ & $13 \%$ \\
\hline \multirow{2}{*}{$\begin{array}{l}\text { Minimum air } \\
\text { temperature }\left({ }^{\circ} \mathrm{C}\right)\end{array}$} & Mean & 6.0 & 3.2 & 0.4 & 7.9 & 9.7 & 3.8 & 1.0 & 9.0 & 10.5 & 14.8 \\
\hline & Change & 0.4 & 0.3 & 0.5 & 0.6 & 0.7 & 0.9 & 0.9 & 0.9 & 0.7 & 1.0 \\
\hline \multirow{2}{*}{$\begin{array}{l}\text { Maximum air } \\
\text { temperature }\left({ }^{\circ} \mathrm{C}\right)\end{array}$} & Mean & 18.9 & 17.1 & 15.4 & 21.9 & 24.4 & 17.3 & 16.7 & 22.9 & 25.4 & 30.0 \\
\hline & Change & 0.2 & 0.3 & 0.1 & 0.3 & 0.3 & 0.3 & 0.3 & 0.4 & 0.4 & 0.3 \\
\hline \multirow{3}{*}{$\begin{array}{l}\text { Potential } \\
\text { evapotranspiration } \\
(\mathrm{mm})\end{array}$} & Mean & 1,042 & 1,055 & 1,018 & 1,279 & 1,365 & 1,179 & 1,194 & 1,381 & 1,470 & 1,523 \\
\hline & Change & 10.4 & 9.2 & 13.7 & 21.9 & 20.3 & 23.7 & 30.1 & 35.6 & 27.0 & 26.5 \\
\hline & \% Change & $1 \%$ & $1 \%$ & $1 \%$ & $2 \%$ & $2 \%$ & $2 \%$ & $3 \%$ & $3 \%$ & $2 \%$ & $2 \%$ \\
\hline \multirow[t]{3}{*}{ Recharge (mm) } & Mean & 504 & 174 & 42 & 103 & 40 & 219 & 49 & 59 & 4 & 1 \\
\hline & Change & -24.2 & -1.9 & -1.0 & 4.0 & 4.5 & 0.4 & 5.9 & -3.0 & 0.9 & 0.3 \\
\hline & \% Change & $-5 \%$ & $-1 \%$ & $-2 \%$ & $4 \%$ & $13 \%$ & $0 \%$ & $14 \%$ & $-5 \%$ & $26 \%$ & $35 \%$ \\
\hline \multirow[t]{3}{*}{ Runoff (mm) } & Mean & 492 & 507 & 87 & 120 & 11 & 319 & 61 & 80 & 3 & 5 \\
\hline & Change & -22.3 & 7.3 & 2.4 & 11.9 & 2.5 & 7.3 & 8.8 & -2.6 & 0.5 & 0.7 \\
\hline & \% Change & $-4 \%$ & $1 \%$ & $3 \%$ & $11 \%$ & $30 \%$ & $2 \%$ & $17 \%$ & $-3 \%$ & $25 \%$ & $17 \%$ \\
\hline \multirow{3}{*}{$\begin{array}{l}\text { Climatic water } \\
\text { deficit }(\mathrm{mm})\end{array}$} & Mean & 558 & 535 & 575 & 863 & 1,065 & 638 & 778 & 1,011 & 1,293 & 1,339 \\
\hline & Change & 1.2 & 9.3 & 25.0 & 9.9 & 2.0 & 24.8 & 36.0 & 30.7 & 20.4 & 13.5 \\
\hline & \% Change & $0 \%$ & $2 \%$ & $5 \%$ & $1 \%$ & $0 \%$ & $4 \%$ & $5 \%$ & $3 \%$ & $2 \%$ & $1 \%$ \\
\hline \multirow{3}{*}{$\begin{array}{l}\text { Snow water } \\
\text { equivalent (mm) }\end{array}$} & Mean & 85 & 227 & 91 & 1 & 0 & 241 & 102 & 12 & 0 & 0 \\
\hline & Change & -33.0 & -34.0 & -16.0 & 0.0 & 0.0 & -27.0 & 8.0 & -2.0 & 0.0 & 0.0 \\
\hline & $\%$ Change & $39 \%$ & $15 \%$ & $18 \%$ & $0 \%$ & $0 \%$ & $11 \%$ & $-8 \%$ & $17 \%$ & $0 \%$ & $0 \%$ \\
\hline
\end{tabular}

Mean value for 1981-2010 and change from 1951-1980.

different. Storms in the Sierra Nevada generate precipitation that saturates the soils and becomes runoff. Springtime snowmelt can also saturate the soils as the majority of an entire winter's precipitation stored as snowpack is released onto the landscape in a couple of months. This differs from the climate on the North coast where the coastal climate results in more evenly distributed temporal patterns of precipitation that allows time for the bedrock to recharge with relatively less runoff.

The change in climate over the last half of the 20th century is exemplified by the observed changes in snowpack in California, which integrate the effects of precipitation and air temperature variability on the dominant water resource in California that is relied upon for water supply. This snowpack region is the warmest in the western US (Lundquist et al. 2009) and is the most sensitive to small changes in air temperature. This is illustrated by the change in April 1st snowpack, calculated as snow water equivalent (SWE), between the periods 1981-2010 and 1951-1980 (Figure 8), where SWE has diminished the most in extent in the northern portions of the state by up to $500 \mathrm{~mm} /$ year, whereas the highest elevation SWE in the central and southern Sierra Nevada has actually increased in some locations up to $500 \mathrm{~mm} /$ year. The increases in air temperature in the Sierra Nevada over the 30 -year time periods, $0.3^{\circ} \mathrm{C}$ maximum air temperature and $0.9^{\circ} \mathrm{C}$ minimum air temperature (Table 1), allow for more moisture to be held in the air, resulting in increases in precipitation, which at high elevations occurs as snow. Although the rising air temperatures have resulted in a rise in the lowest elevation at which snowpack may develop, locations with minimum winter temperatures well below freezing have generally increased in SWE, such as Mount Shasta and the high elevation southern Sierra Nevada (Mote 2006). The loss of April 1st SWE results in less runoff to extend the water resource throughout the summer season. This has implications for recharge and climatic water deficit as well. Average April 1st SWE has declined in all ecoregions that have an annual snowpack, except the eastern Sierra Nevada, by as much as 39\% in northwestern CA, and the dominant snowpack region, the Sierra Nevada, has seen a reduction of $11 \%$ over the two time periods.

CWD patterns over the California region are similar to those of PET (Figure 9a, c), with CWD as low as 


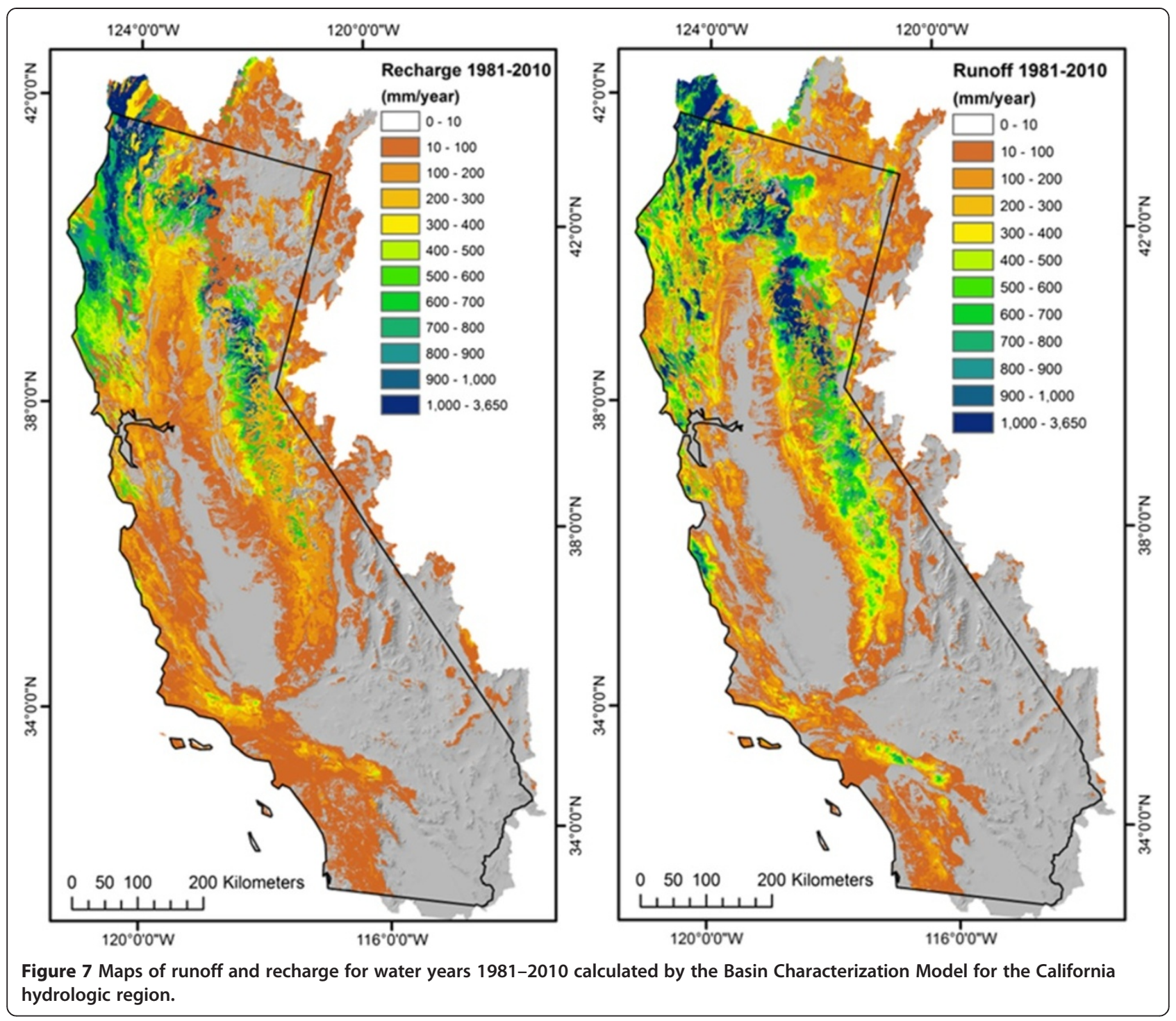

$400 \mathrm{~mm} /$ year in mountain regions and as high as 1,700 $\mathrm{mm} /$ year in deserts and regions with low precipitation. The actual evapotranspiration is highest where there is ample available water to maintain evapotranspiration (Figure 9b). The lowest CWD is in regions with snowpack that, as it melts in the springtime, provides a longer duration of available water, thus maintaining a lower annual deficit, even despite shallow soils. Locations in the south with higher PET have higher deficits.

\section{Fine-scale applications}

Although precipitation has generally increased between the two time periods evaluated here for California, the increases in air temperature and PET translate into increases in CWD in many locations, particularly those dominated by snowpack, such as the Sierra Nevada or Modoc Plateau ecoregions, which have increased in CWD by 4 and $5 \%$, respectively, over the two 30 -year periods.
Fine-scale modeling and analysis permit the influence of elevation and aspect to appear as CWD changes, relying also on the fine-scale attributes of mapped soils. Examples of CWD under higher than average annual precipitation (water year 1998; Figure 10a) and lower than average annual precipitation (water year 1977; Figure 10b) indicate the influence of energy loading on slopes. This area west of Lake Tahoe in the American River basin has annual snowpack that provides low CWD in a wet year across the area. In fact, a wet year looks very much like an average year in other parts of the Sierra Nevada because the soils are generally shallow and excess water readily becomes runoff. A dry year shows the influence of less snowpack, and much of the landscape on the left side of Figure 10b, which is at lower elevations and receives less snow, dries out over the season, thereby increasing the annual CWD. This is true except for landscapes shown at the bottom of both figures, noted in the oval, where in the center is a 


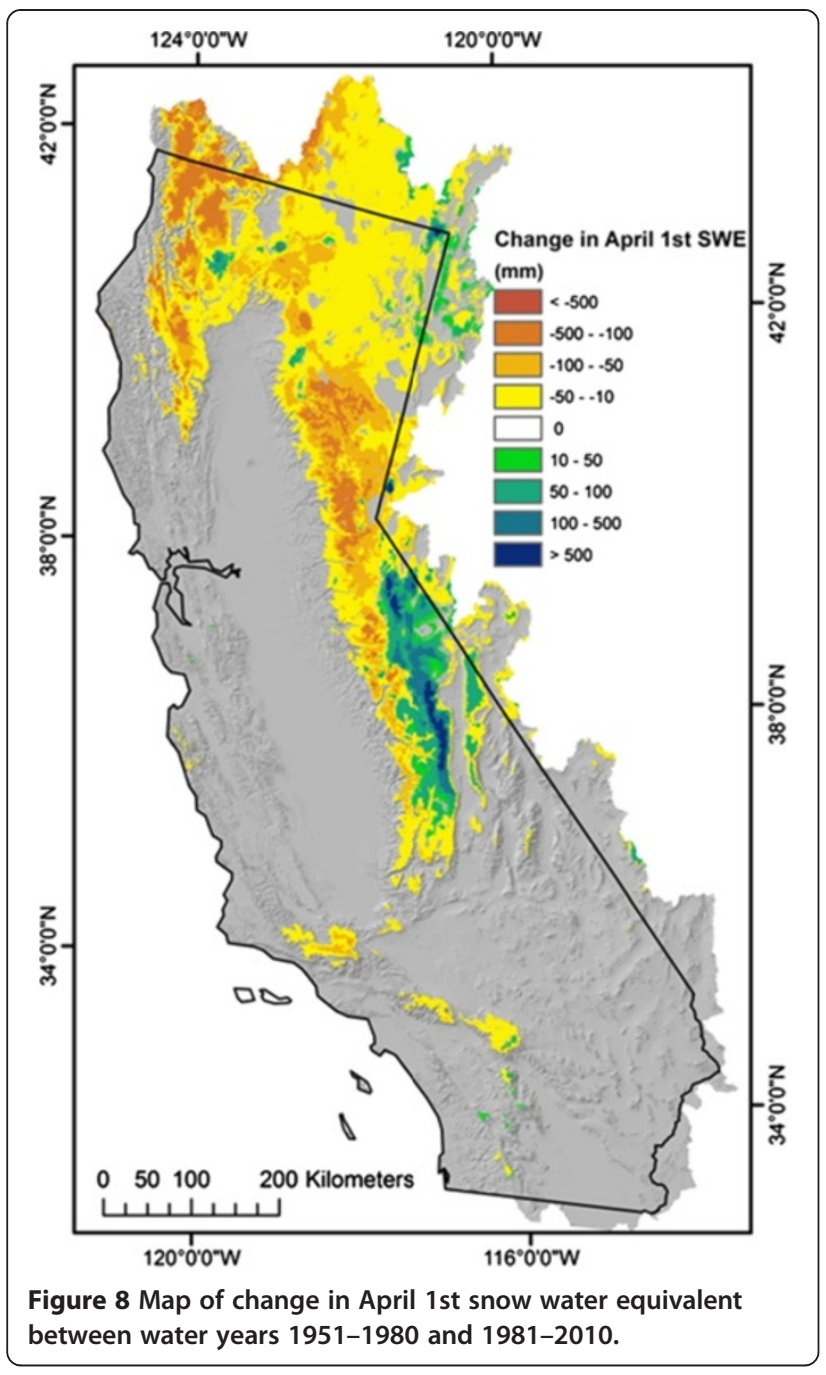

large north-facing hillslope that maintains low energy loading and thus a low CWD, even in a dry year. The application of water-balance modeling at 270-m resolution allows the representation of this process at the scale of hillslopes.

The evaluation of extreme years and the potential implications of projected climate change can also be seen in the depiction of precipitation, potential evapotranspiration, actual evapotranspiration, runoff, and recharge for a landscape-scale view across northern California (Figure 11). This view from the North Bay counties across the Sacramento Valley and into the northern Sierra Nevada illustrates the range in precipitation across the region in wet and dry years, while the PET changes little due to air temperature. Actual evapotranspiration in 1998 is high in soils that can store water, such as those in the Central Valley, or where it is cooler with shallower soils, such as in the eastern foothills of the Sierra Nevada. In a dry year the Central Valley has lower actual evapotranspiration because supply was low. Low rainfall corresponds to low recharge or runoff as well, while in a wet year recharge is high in the Central Valley deep soils and runoff is high in locations with low permeability bedrock or shallow soils (Figure 11).

Additional implications of fine-scale modeling can be seen in two depictions of the change in CWD between the periods 1981-2010 and 1951-1980. In Figure 12a, located in the Modoc Plateau, most of the area in the figure consists of warmer colors, indicating an increase in CWD. At this scale it is noticeable by the rings around the mountain tops indicating that the snow line has receded up the mountainsides in two locations, increasing the CWD in the band no longer covered by snow. In a location with no snowpack in the central coast, just east of Monterey Bay (Figure 12b), the change in climate over this local area has increased the CWD variably across the landscape. It is clear at a fine scale that north-facing slopes are more resilient to change in climate and that several valleys have not changed as much as the surrounding uplands, which is due to deeper soils in the valley bottoms maintaining moisture longer into the season.

\section{Discussion}

\section{California hydrologic region}

Steep elevation gradients, a long temperate coastline, a large latitudinal extent, and a variety of geological histories provide the regional spatial framework for assessing potential hydrologic response across the California hydrologic region. Inclusion of topographic and soils details creates a more comprehensive view of underlying watershed variability that, in turn, we know supports high levels of biodiversity. The range of hydrologic response to these conditions across California is exemplified by the range and variation in runoff and recharge (ranging from approximately 0 to over $500 \mathrm{~mm} /$ year), while the dynamics of snowpack indicate the vulnerability of a region reliant on springtime snowpack to rising air temperatures.

Increasingly warmer climate conditions over time drive estimated increases in CWD, which are highly sensitive to increases in air temperature. Increases in precipitation do not uniformly lower end-of-year CWD because resulting increases in excess water can be either retained in soil storage or converted to recharge or runoff early in the season. Therefore, even in the face of potentially increasing amounts of seasonal precipitation in this Mediterranean climate, with higher temperatures CWD tends to increase during the months following the conclusion of the rainy period in a way that essentially offsets any effects of precipitation increases on soil moisture. This fine-scale representation of CWD dynamics enables the identification of landscape features and habitats that may resist significant climatic changes in the future. We observe that northfacing slopes with relatively low energy loads are less sensitive in terms of drought stress to dramatically lower- 


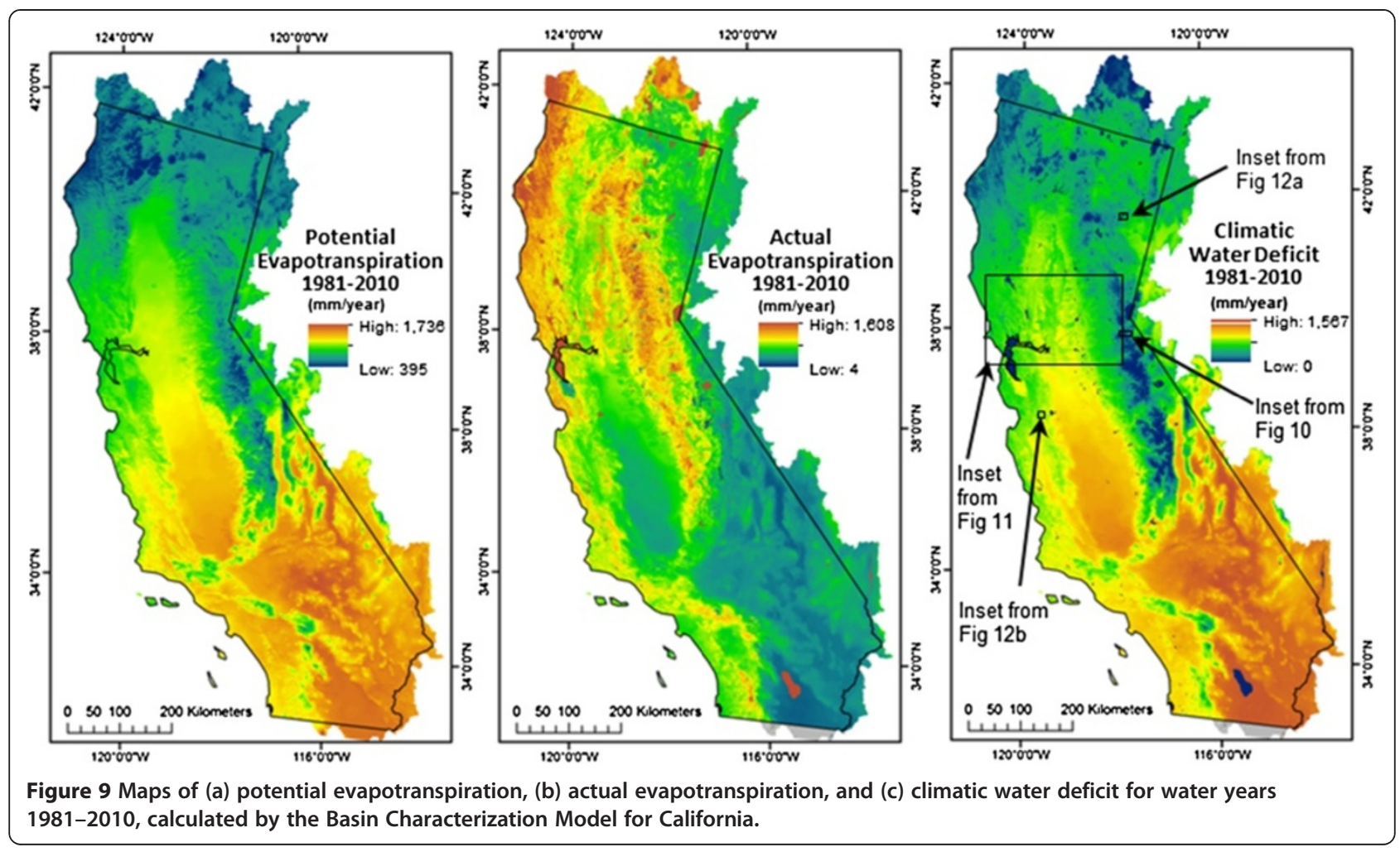

than-average precipitation years. We also observe that the CA-BCM validates that deeper soils in valley bottoms are capable of sustaining more moisture longer into the dry season than environments with thin soils. Using these tools, managers seeking to maximize biodiversity and ecosystem health can identify local climate refugia for vulnerable species.

\section{BCM performance}

The utility of the BCM to assess unimpaired hydrologic conditions for California relies on thoroughly characterizing underlying geology based in part on the use of streamgage data to calibrate the hydrologic balance between recharge and runoff. In this study we assembled runoff data from 159 streamgages and reconstructions, which permitted an assessment of how well the CA-BCM model performs at integrating all the hydrologic balance components. Other components of the CA-BCM could potentially also be calibrated as well (Figure 2). For example, model calibrations were previously performed for the solar radiation and evapotranspiration components (Flint and Flint 2007). Soil moisture and climatic water deficit could be field verified as well through spatial and temporal sampling of plant evapotranspiration rates (e.g. Ryu et al. 2008) and by direct measures of soil moisture (e.g. Mittelbach et al. 2011). The application of this mechanistic model permits a look at how conditions have changed over time and provides an illustration of where basins are more or less sensitive to changes in climate, where runoff or recharge processes are dominant, and where climate-driven moisture stresses to the landscape are likely to be more or less profound.

Simulated and measured results were comparable in basins throughout the state for both unimpaired and impaired (including impacts due to urban and agricultural conditions) basins based on close matches of estimated basin discharge to measured streamflow. Basins with the lowest BCM performance in terms of calibration statistics contained unaccounted-for land uses, such as agricultural or municipal diversions or return flows, or water impoundments such as reservoirs. These results provide reasonable confidence in the spatially distributed BCM estimates of recharge, runoff, and climatic water deficit throughout the entire state, including ungaged basins. However, runoff in the BCM is not explicitly routed within the model, and basin discharge requires post-processing using measured streamflow to determine the relative contributions of recharge and runoff in a basin to gains and losses in streamflow. Once established, these components can be used to extrapolate basin discharge through time, assuming no changes in impairments. Uncertainties in calibration do not impact estimates of CWD as this calculation does not rely on the bedrock permeability used to partition the excess water into recharge and run off. Soil water conditions are a function of soil properties, available water from precipitation, and 


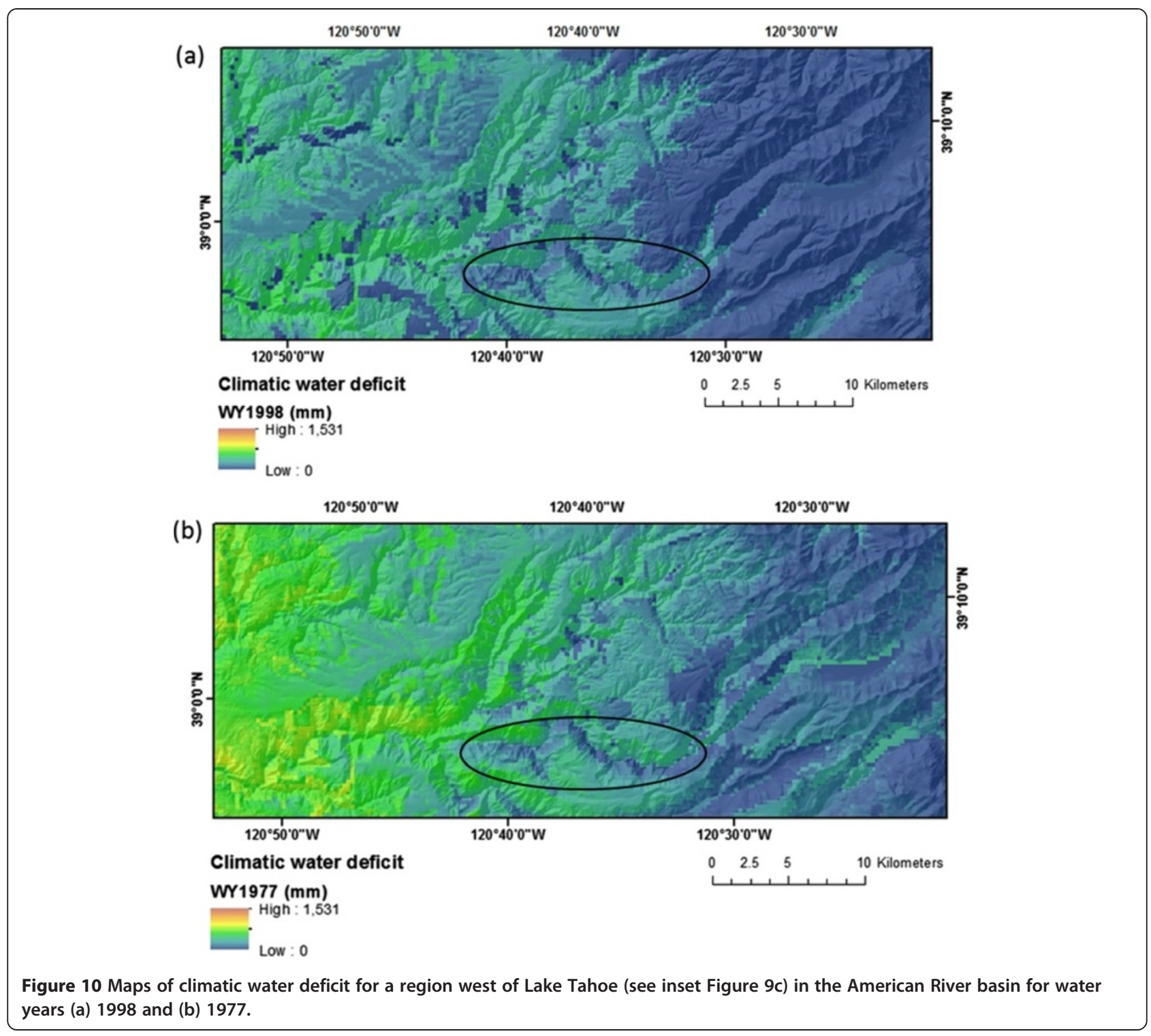

evapotranspiration. Therefore, the BCM calculation of CWD equals PET minus AET (Stephenson 1998) reflects the uncertainties inherent in the climate data, in the soil properties from soil mapping, and in PET.

\section{Model and data limitations}

A highly valuable application of the BCM beyond the estimates of spatially distributed recharge and runoff would be to estimate basin discharge for ungaged basins. We attempted to correlate equation coefficients (scaling factors and exponents in Equations 1 to 7) developed in gaged basins to landscape variables such as geology, soil properties, slope, basin area, or aridity to provide an empirical basis for estimating discharge in ungaged basins. This endeavor was unsuccessful on a statistically significant basis across all calibration basins, possibly due to potential errors in the soils or geology maps, or in the PRISM climate data, or due to human activities that are affecting basin hydrology at the watershed scale. However, general regional characteristics that influence the hydrology in a basin can be used to extrapolate discharge to ungaged basins. For example, observations of high baseflow in basins with high bedrock permeability might be correlated across multiple basins, and basins of similar size and soils in close proximity may share equation coefficients to estimate discharge. Since the BCM is a mechanistic model, driven by a series of assumptions about the physical environment, we argue that the model output is of value for regional comparisons of watersheds, even in the absence of independent validation for ungaged basins. As with any rainfall-runoff model development, there is a good deal of art and empiricism associated with calibration, and extrapolation of discharge to ungaged basins remains an uncertain enterprise. However, if we assume that the watershed properties and climate are 


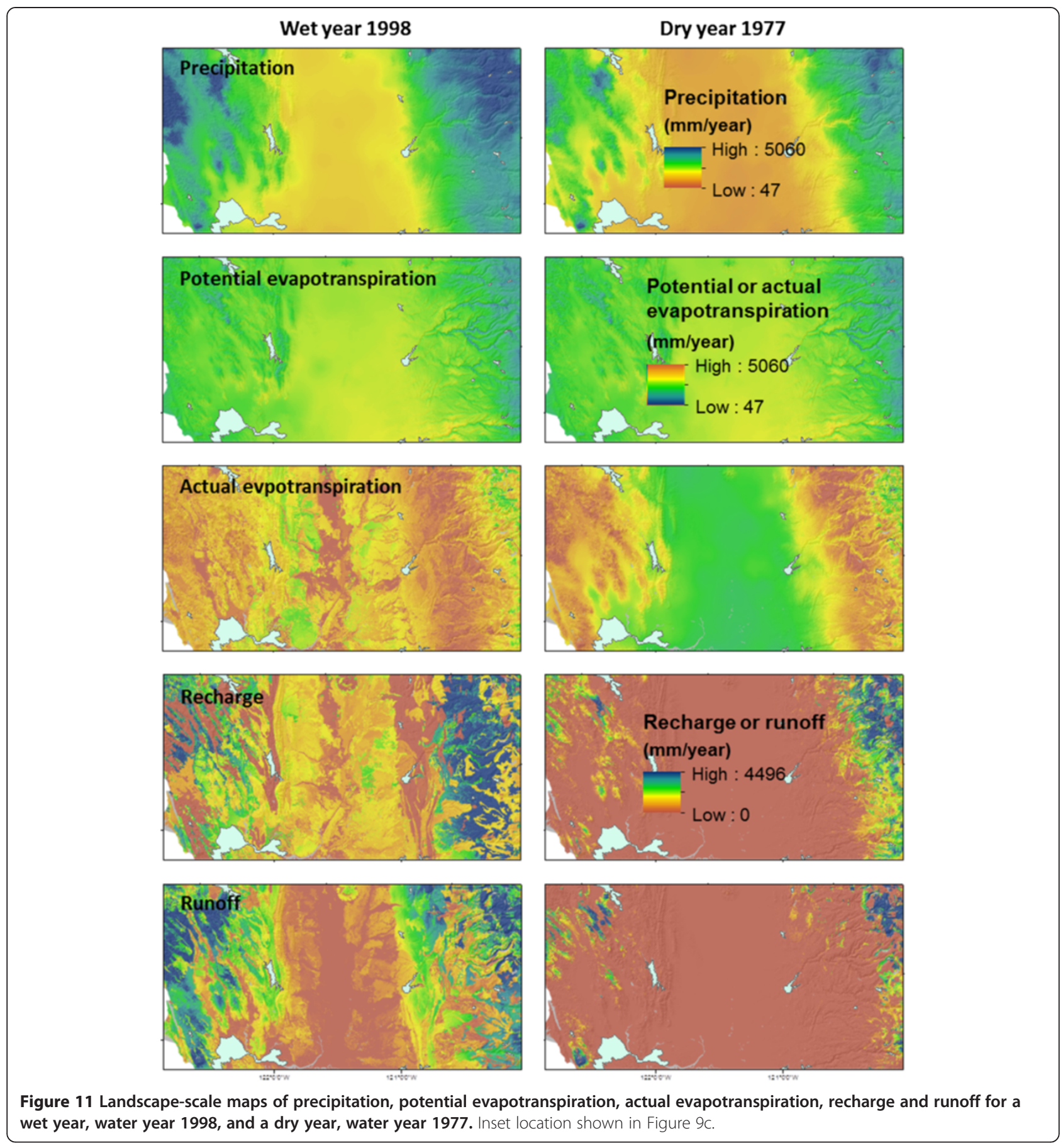

correctly characterized, the $\mathrm{BCM}$ hydrologic outputs are based on properties that are spatially distributed throughout the study area, and the calculations are performed consistently across all basins, this provides a significant level of confidence in results for regional cross-comparisons of basins.

Some of the potential sources of error in input variables are well known to geographers. Soils maps are particularly prone to error since accurate measures of soil depth are difficult to measure and currently unobtainable for large areas. County-level soils maps (SSURGO) provide very good spatial detail on soil types and properties but are limited in locations with soil depths greater than $2 \mathrm{~m}$.

Human activities are extensive in California and likely have some degree of impact in nearly every basin. Activities that can affect the hydrologic cycle at the watershed scale include small impoundments, direct pumping from 


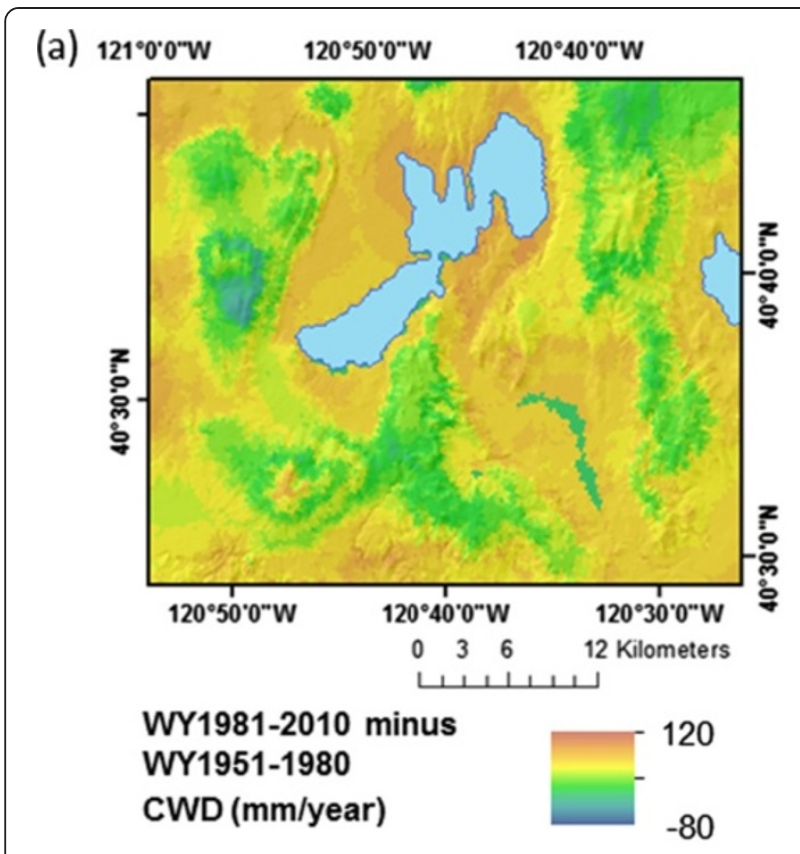

(b)
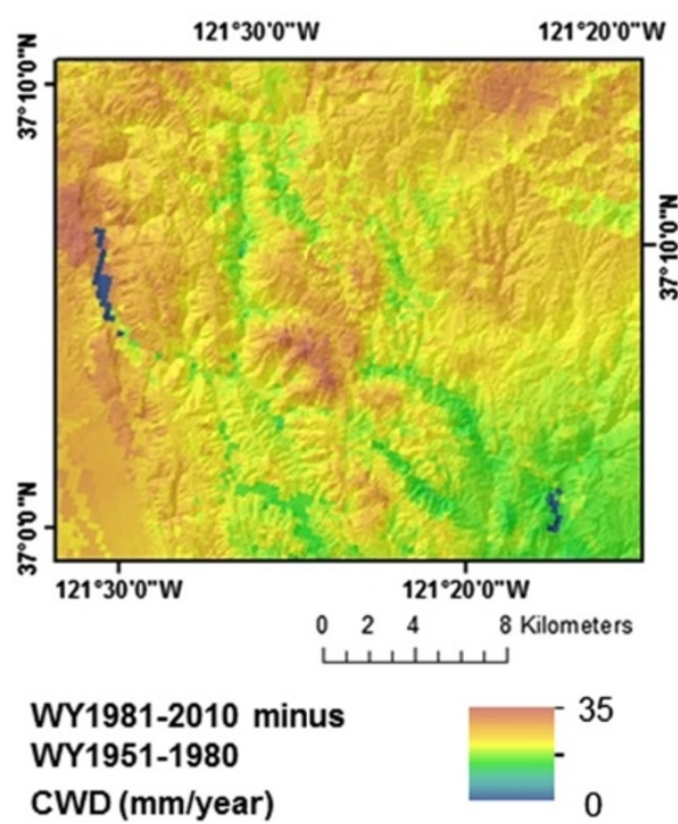

Figure 12 Close-up maps of the change in climatic water deficit between water years 1981-2010 and 1951-1980 for areas (a) in the Modoc Plateau and (b) central coast of California. Inset location shown in Figure 9c.

streams for urban or agricultural use, construction of impermeable surfaces, and changes to the natural land cover. These can affect variously the partitioning of input PPT to different pathways in the hydrologic cycle and also the actual evapotranspiration (AET) and PET calculated as part of the model. We were not able to make a detailed assessment of the influence of human activities on the overall model accuracy and feel this is a future research agenda, particularly for basins with several gages that are placed below and above areas of human disturbance. If the model is adequately parameterized to estimate basin discharge in unimpaired locations, then the model can be used to assess nearby locations with similar physical watershed characteristics that are ungaged. Similarly, the model could be used to assess the degree of impact that impairments may have on basin discharge.

The estimate of spatially distributed runoff does not equal basin discharge as measured at a streamgage without post-processing to determine the components of runoff and recharge that contribute to stream channel gains and losses, which must be done using some measured data for a given basin. The resultant parameters corresponding to the gains and losses generally reflect climatic conditions and geologic setting, but at the scale of California have not been determined to a degree that allows for the direct extrapolation of basin discharge to all ungaged basins. The spatial distribution of runoff and recharge, however, provides relative differences over the region and can indicate the differences in sensitivity of basins to changes in climate. The estimates of changes in soil moisture and CWD do not rely on interpretation of bedrock permeability, and uncertainties correspond more closely with those of the mapped soil properties and climate data.

Because the BCM model outputs are calculated on a grid-cell basis, results can be summarized across landscapes using summary units of any size of interest such as watersheds, ecoregions, or political boundaries. The ability to spatially project hydrologic model outputs permits the cross-comparison of these landscape delineations, with mapped outputs of interest to various fields of research. The limitations to the appropriate spatial application can be quite small if the underlying input properties are accurate because the energy load calculations are based on the resolution of the digital elevation model, in this case, 270 $\mathrm{m}$. The variables most closely associated with energy loads (PET, AET, CWD) could potentially be applied at the hillslope scale, given the resolution of SSURGO soils data for most locations. However, it is recommended that most hydrologic applications be considered at no less than the size of planning watersheds (Natural Resources Conservation Service's California Interagency Watershed Mapping Committee; CalWater 1999).

The ability to calculate hydrologic outputs using a transparent, mechanistic approach, and at fine spatial scales, permits a new set of predictor variables to be used in the spatial projection of suitable plant ranges or habitats (e.g. Williams et al. 2009). This is a particularly important opportunity for ecologists and conservation biologists because species distribution models are one of the primary methods of evaluating the susceptibility of 
species to climate change (e.g. Guisan and Thuiller Guisan and Thuiller 2005; Loarie et al. 2009). The discharge and groundwater outputs can inform water management for storage, human consumption, and anadromous fisheries. One of the most important variables that BCM calculates is climatic water deficit (Stephenson 1998). Natural resource managers and field ecologists are particularly interested in this variable, as it integrates site conditions with temperature and moisture, and is therefore a factor that plants may respond to more directly than climate variables alone, particularly in regions with pronounced seasons. The strength of the BCM in portraying CWD is that different watersheds can be compared by identifying the areaweighted mean value. Therefore relative differences across hydrologic California are comparable. Soil moisture and climatic water deficit are also of interest for tracking suitability of rain-fed agriculture and for assessment of suitability of natural environments for component plants and animals.

\section{Conclusions}

The downscaling of historical climate data for application to the BCM to calculate hydrologic response to ongoing changes in climate has provided a dataset rich in regional representation of climatic and hydrologic trends, but spatially detailed enough to provide fine-scale examples of local impacts of climate on the landscape.

Landscape responses to current changes in climate can be moderated in locations with relatively low energy loads, such as north-facing hillslopes or coastal regions with frequent cloud cover. Soil also amplifies or moderates the hydrologic response of the landscape depending on whether soils are thin and excess water is easily lost to runoff or recharge or whether they are thick and therefore can maintain moisture longer into the dry season. Mountainous regions seasonally occupied by snowpack are quite sensitive to ongoing changes in climate as the timing of snowmelt is enhanced by warming thus changing the length of the wet season and extending the dry season for all regions downstream that rely on snowpack for public and agricultural use.

The CA-BCM, using the best map data available, still shows we have not captured all the details that drive individual watershed dynamics. However, for comparative purposes across a large number of watersheds and ecoregions, the relative consistency of the model permits informative interpretations. This is, in essence, very similar to the way in which Global Climate Models themselves run, in that they provide a platform for intercomparison of regions even while they may be more or less accurate when compared to ground-based measurements. In this regard, then, the next challenge for modelers of these physical (and biophysical) processes is to determine how to incorporate an increasingly finer scale of detail as these data become available. CA-BCM output maps indicate where on the landscape significant changes in the hydrologic cycle may occur. If, at the watershed scale, basin discharge or recharge boundary conditions are needed, then this study suggests some local calibration is necessary. However, if the basins are purely unimpaired, then nearby or adjacent basin calibration is likely to suffice.

The consistent patterns offered by the CA-BCM for a wide variety of biophysical variables make the model output of particular interest to landscape ecologists, including those interested in modeling the biogeographic response of species and vegetation types to future changes in climate. Part of the interest derives from the fact that future moisture conditions are much more difficult to project than future temperature, a fact that emerges when comparing the outputs of future GCMs for temperature and precipitation, where there is much higher agreement between models for temperature. Having a mechanistic model that captures the dynamics of the water that is predicted permits a better estimation of hydrologic conditions under different scenarios, which in turn can provide a view to the range of potential impacts to water available for natural processes and for human uses. It also provides an opportunity to compare estimated unimpaired conditions to current levels of impairment, given sufficient site-specific data.

Because of the modular nature of the Basin Characterization Model, it is possible to make two types of improvements. First, any particular module's calculations may be updated and improved. An example would be if PET values for different vegetation types could be calculated, these could be applied using an existing vegetation map to render more accuracy in the plant-driven parts of the model. Second, input data maps may be updated and improved. Ongoing refinements are currently to apply a radiation function to the Snow-17 snowmelt algorithm, which relies solely on air temperature to melt snow. This will enhance the timing of snowmelt in mountainous regions, especially during warming conditions when springtime snowmelt occurs earlier in the season and the sun angle is lower on the horizon inducing more variation in shading. Additionally, local studies are providing more information for improved calibrations and refinements in geologic maps.

\section{Additional file}

Additional file 1: Calibration and validation basins used for the California Basin Characterization Model with streamgages, equation coefficients for the calculation of basin discharge, and goodness-of-fit statistics.

\section{Competing interests}

The authors declare that they have no competing interests. 


\section{Authors' contributions}

AF wrote and refined the computer code for the CA-BCM, LF calibrated the model, LF and JT analyzed results, AF and RB ran model simulations, LF and JT drafted and revised the manuscript, and AF and RB reviewed and revised the manuscript. All authors read and approved the final manuscript.

\section{Acknowledgments}

The authors acknowledge the California Energy Commission Public Interest Energy Research 2010 Climate Change Vulnerability and Adaptation study, Sonoma County Water Agency, Santa Cruz Environmental Health Department, California Department of Water Resources, and U.S. Geological Survey Climate Change Initiative for support of various aspects of this research.

\section{Author details}

${ }^{1}$ Water Resources Discipline, U.S. Geological Survey, Placer Hall, 6000 J Street, Sacramento, CA 95819-6129, USA. IInformation Center for the Environment, University of California, Davis, CA 95616, USA

Received: 27 January 2013 Accepted: 11 July 2013

Published: 31 July 2013

\section{References}

Alkama R, Decharmen B, Douville H, Ribes A (2011) Trends in global and basin-scale runoff over the late twentieth century: methodological issues and sources of uncertainty. J Climate 24:3000-3014

Alley WM (1984) On the treatment of evapotranspiration soil moisture accounting, and aquifer recharge in monthly water balance models. Water Resour Res 20:1137-1149

Anderson EA (1976) A point energy and mass balance model of a snow cover. Technical report NWS 19, 150 p. U.S. National Oceanographic and Atmospheric Administration (NOAA). Silver Spring, MD

CalWater (1999) California interagency watershed map of 1999 (CalWater version 2.2.1). Prepared by the Natural Resources Conservation Service California Interagency Watershed Mapping Committee. http://cain.ice.ucdavis.edu/ calwater/

Chiew FHS, Kirono DGC, Kent DM, Frost AJ, Charles SP, Timbal B, Nguyen KC, Fu G (2010) Comparison of runoff modeled using rainfall from different downscaling methods for historical and future climates. J Hydrol 387:10-23

Curtis JA, Flint LE, Flint AL, Lundquist JD, Hudgens B, Boydston EE, Young JK (In review) Application of a regional-scale hydrologic model to assess impacts on snow-dependent ecology under current and future climates in the Sierra Nevada. , CA

Daly C, Halbleib M, Smith Jl, Gibson WP, Doggett MK, Taylor GH, Curtis BJ, Pasteris PP (2008) Physiographically sensitive mapping of climatological temperature and precipitation across the conterminous United States. Int J Climatol 28:2031-2064

DWR (California Department of Water Resources) (2007) California Central Valley unimpaired flow data, 4th edition. DWR Bay-Delta Office, Sacramento, CA

Flint AL, Childs SW (1987) Calculation of solar radiation in mountainous terrain. J Agr Forest Meteor 40:233-249

Flint AL, Childs SW (1991) Modification of the Priestley-Taylor equation to estimate evapotranspiration for soil water limited conditions. J Agr Forest Meteor 56:247-260

Flint LE, Flint AL (2006) Impacts of Tioga Road on groundwater flow in Tuolumne Meadows: preliminary conceptual model and numerical analysis. In: Cooper DJ, Lundquist JD, King J, Flint AL, Flint LE, Wolf E, Lott FC (ed) Effects of the Tioga Road on hydrologic processes and Lodgepole Pine invasion into Tuolumne Meadows. Yosemite National Park. Report prepared for Yosemite National Park

Flint LE, Flint AL (2007) Regional analysis of ground-water recharge. Ground-water recharge in the arid and semiarid southwestern United States. In: Stonestrom DA, Constantz J, Ferré TPA, Leake SA (ed) Ground-water recharge in the arid and semiarid southwestern United States. US Geol Surv Prof Paper 1703, pp 29-59

Flint LE, Flint AL (2008) A basin-scale approach to estimating stream temperatures of tributaries to the Lower Klamath River. California, J Environ Qual 37:57-68

Flint LE, Flint AL (2012a) Simulation of climate change in San Francisco Bay basins, California: case studies in the Russian river valley and Santa Cruz mountains. US Geol Surv Sci Invest Rep 5132:55
Flint LE, Flint AL (2012b) Downscaling future climate scenarios to fine scales for hydrologic and ecological modeling and analysis. Ecol Processes 1:2

Flint AL, Flint LE, Kwicklis EM, Bodvarsson GS, Fabryka-Martin JT (2002a) Hydrology of Yucca Mountain. Rev Geophys 39:447-470

Flint AL, Flint LE, Kwicklis EM, Fabryka-Martin JT, Bodvarsson GS (2002b) Estimating recharge at Yucca Mountain, Nevada, USA: comparison of methods. Hydrogeol J 10:180-204

Flint AL, Flint LE, Masbruch MD (2011) Input, calibration, uncertainty, and limitations of the basin characterization model: appendix 3 of conceptual model of the Great Basin carbonate and alluvial aquifer system. In: Heilweil VM, Brooks LE (ed) U.S. Geological Survey scientific investigations report 2010-5193. USGS, Reston, VA

Flint LE, Flint AL, Stolp BJ, Danskin WR (2012) A basin-scale approach for assessing water resources in a semiarid environment: San Diego region, California and Mexico. Hydrol Earth System Sci 16:1-17

Gee GW, Hillel D (1988) Groundwater recharge in arid regions: review and critique of estimation methods. Hydrol Processes 2:255-266

Girvetz EH, Zganjar C, Raber GT, Maurer EP, Kareiva P, Lawler JJ (2009) Applied climate-change analysis: the climate wizard tool. PLoS ONE 12:e8320. doi:10.1371/journal.pone.0008320

Guisan A, Thuiller W (2005) Predicting species distribution: offering more than simple habitat models. Ecol Lett 8:993-1009

Hay LE, Markstrom SL, Ward-Garrison C (2011) Watershed-scale response to climate change through the twenty-first century for selected basins across the United States. Earth Interactions 15(17):1-37

Hevesi JA, Flint AL, Flint LE (2003) Simulation of net infiltration and potential recharge using a distributed-parameter watershed model of the death valley region. U.S. Geological Survey Water Resources Investigations Report 03-4090. USGS, Reston, VA

Hickman JC (1993) The Jepson manual: higher plants of California. University of California Press, Berkeley, CA

Hillel D (1980) Fundamentals of soil physics. Academic, New York

Hopp L, McDonnell JJ (2009) Connectivity at the hillslope scale: identifying interactions between storm size, bedrock permeability, slope angle and soil depth. J Hydrol 376:378-391

Hutchinson DG, Moore RD (2000) Throughflow variability on a forested hillslope underlain by compact glacial till. Hydrol Processes 14(10):1751-1766

Jennings CW (1977) Geologic map of California. California Division of Mines and Geology geologic data. Map number 2, scale 1:750,000

Jones JP, Sudicky EA, McLaren RG (2008) Application of a fully-integrated surface subsurface flow model at the watershed-scale: a case study. Water Resour Res 44(W03407):13

Leavesley GH, Branson MD, Hay LE (1992) Using coupled atmospheric and hydrologic models to investigate the effects of climate change in mountainous regions. In: Herrmann R (ed) Managing water resources during global change. American Water Resources Assocation, Middleburg, VA, pp 691-700

Legates DR, McCabe GJ, Jr (1999) Evaluating the use of 'goodness-of-fit' measures in hydrologic and hydroclimatic model validation. Water Resourc Res 35:233-241

Liang X, Lettenmaier DP, Wood E, Burges SJ (1994) A simple hydrologically based model of land surface water and energy fluxes for general circulation models. J Geophys Res 99:14415-14428

Littell JS, Peterson DL, Millar CL (2012) U.S. National Forests adapt to climate change through science-management partnerships. Climactic Change 110:260-296

Loarie SR, Duffy PB, Hamilton H, Asner GP, Field CB, Ackerly DD (2009) The velocity of climate change. Nature 462:1052-1055

Lundquist JD, Dettinger MD, Stewart IT, Cayan DR (2009) Variability and trends in spring runoff in the western United States. In: Wagner F (ed) Climate warming in western North America-evidence and environmental effects. University of Utah Press, Salt Lake City, pp 63-76

Marcarelli AM, Van Kirk RW, Baxter CV (2010) Predicting effects of hydrological alternation and climate change on ecosystem metabolism in a western U. S. river. Ecol Appl 20:2081-2088

Mauer EP, Brekke LD, Pruitt T (2010) Contrasting lumped and distributed hydrology models for estimating climate change impacts on California watersheds. J Amer Water Resources Assoc 46:1024-1035. doi:10.1111/j. 1752-1688.2010.00473.x

Micheli E, Flint LE, Flint AL, Weiss SB, Kennedy M (2012) Downscaling future climate projections to the watershed scale: a north San Francisco Bay estuary case study. San Francisco Estuary Watershed Sci 10(4) 
Mittelbach H, Casini F, Lehner I, Teuling AJ, Seneviratne SI (2011) Soil moisture monitoring for climate research: evaluation of a low-cost sensor in the framework of the Swiss soil moisture experiment (SwissSMEX) campaign. J Geophys Res 116(D05111):11p. doi:10.1029/2010JD014907

Mote PW (2006) Climate-driven variability and trends in mountain snowpack in western North America. J Climate 19:6209-6220

Nalder IA, Weins RW (1998) Spatial interpolation of climatic normals, test of a new method in the Canadian boreal forest. Agric Forest Meteor 92:211-225. doi:10.1126/science. 1151915

Nash JE, Sutcliffe JV (1970) River flow forecasting through conceptual models. I. A discussion of principles. J Hydrol 10:282-290

NRCS (Natural Resources Conservation Service) (2006) U.S. General Soil Map (SSURGO/STATSGO2). http://www.ftw.nrcs.usda.gov/stat_data.html, http:// soils.usda.gov/survey/geography/statsgo/description.html

Parmesan C (2006) Ecological and evolutionary responses to recent climate change. Ann Rev Ecol Evol System 37:637-669

Priestley CHB, Taylor RJ (1972) On the assessment of surface heat flux and evaporation using large-scale parameters. Monthly Weather Rev 100:81-92

Ragab R (1996) Constraints and applicability of irrigation scheduling under limited water resources, variable rainfall and saline conditions. In: Food and Agricultural Organization of the United Nations (FAO) (ed) Irrigation scheduling: from theory to practice. FAO, Rome, pp 149-165

Risley J, Moradkhani H, Hay L, Markstrom S (2011) Statistical comparisons of watershed-scale response to climate change in selected basins across the United States. Earth Interactions 15(14):1-26

Ryu Y, Baldocchi DD, Ma S, Hehn T (2008) Interannual variability of evapotranspiration and energy exchange over an annual grassland in California. J Geophys Res 113(D09104):16. doi:10.1029/2007JD009263

Sanford WE, Plummer LN, McAda DP, Bexfield LM, Anderholm SK (2001) Estimation of hydrologic parameters for the groundwater model of the middle Rio Grande basin using carbon-14 and water-level data. In: Cole JC (ed) U.S. Geological Survey middle Rio Grande basin study: proceedings of the fourth annual workshop. US Geol Surv Open-File Rep 00-488, Albuquerque, New Mexico, 15-16 February 2000, pp 4-6

Stephenson NL (1998) Actual evapotranspiration and deficit: biologically meaningful correlates of vegetation distribution across spatial scales. J Biogeog 25(5):855-870

Thorne JH, Boynton R, Flint LE, Flint AL, Le TN (2012) Development and application of downscaled hydroclimatic predictor variables for use in climate vulnerability and assessment studies. CEC-500-2012-010. California Energy Commission, Sacramento

Thorne JH, Flint LE, Flint AL, Boynton R (2013) Comparing historic and future climate and hydrology for California watersheds using the basin characterization model. Ecosphere: in press

Trnka M, Olesen JE, Kersebaum KC, Skjelvag AO, Eitzinger J, Seguin B, Peltonen-Sainio P, Rotter R, Iglesias A, Orlandini S, Dubrovsky M, Hlavinka P, Balek J, Eckersten H, Cloppet E, Calanca P, Gobin A, Vucetic V, Nejedlik P, Kumar S, Lalic B, Mestre A, Rossi F, Kozyra J, Alexandrov V, Semeradova D, Zalud Z (2012) Agroclimatic conditions in Europe under climate change. Glob Change Biol 17:2298-2318

Tromp-van Meerveld HJ, Peters NE, McDonnell JJ (2007) Effect of bedrock permeability on subsurface stormflow and the water balance of a trenched hillslope at the Panola Mountain research watershed, Georgia, USA. Hydrol Processes 21:750-769

Williams JN, Seo C, Thorne JH, Nelson JK, Erwin S, O'Brien JM, Schwartz MW (2009) Using species distribution models to predict new occurrences for rare plants. Diversity Distributions 15:565-576

Wood AW, Maurer EP, Kumar A, Lettenmaier DP (2002) Long range experimental hydrologic forecasting for the eastern U.S. J Geophys Res 107:4429

doi:10.1186/2192-1709-2-25

Cite this article as: Flint et al:: Fine-scale hydrologic modeling for regional landscape applications: the California Basin Characterization

Model development and performance. Ecological Processes 2013 2:25.

\section{Submit your manuscript to a SpringerOpen ${ }^{\odot}$ journal and benefit from:}

- Convenient online submission

- Rigorous peer review

- Immediate publication on acceptance

- Open access: articles freely available online

- High visibility within the field

- Retaining the copyright to your article

Submit your next manuscript at $\gg$ springeropen.com 